\title{
Diagnostic and Prognostic Indications of Nasopharyngeal Carcinoma
}

\author{
Engku Nur Syafirah E. A. R. ${ }^{1}(\mathbb{0})$ Ahmad Adebayo Irekeola ${ }^{1,2}$ (i) and Chan Yean Yean ${ }^{1,3, *(1)}$ \\ 1 Department of Medical Microbiology and Parasitology, School of Medical Sciences, Universiti Sains \\ Malaysia, Health Campus, Kubang Kerian 16150, Kelantan, Malaysia; \\ engkunursyafirah@gmail.com (E.N.S.E.A.R.); profahmad007@yahoo.com (A.A.I.) \\ 2 Department of Biological Sciences, Microbiology Unit, College of Natural and Applied Sciences, \\ Summit University Offa, Offa PMB 4412, Kwara State, Nigeria \\ 3 Hospital Universiti Sains Malaysia, Universiti Sains Malaysia, Health Campus, Kubang Kerian 16150, \\ Kelantan, Malaysia \\ * Correspondence: yeancyn@yahoo.com; Tel.: +609-767-6258
}

Received: 12 July 2020; Accepted: 18 August 2020; Published: 19 August 2020

\begin{abstract}
Nasopharyngeal carcinoma (NPC) is a disease that is highly associated with the latent infection of Epstein-Barr virus. The absence of obvious clinical signs at the early stage of the disease has made early diagnosis practically impossible, thereby promoting the establishment and progression of the disease. To enhance the stride for a reliable and less invasive tool for the diagnosis and prognosis of NPC, we synopsize biomarkers belonging to the two most implicated biological domains (oncogenes and tumor suppressors) in NPC disease. Since no single biomarker is sufficient for diagnosis and prognosis, coupled with the fact that the known established methods such as methylation-specific polymerase chain reaction (PCR), multiplex methylation-specific PCR, microarray assays, etc., can only accommodate a few biomarkers, we propose a 10-biomarker panel (KIT, LMP1, PIKC3A, miR-141, and miR-18a/b (oncogenic) and p16, RASSF1A, DAP-kinase, miR-9, and miR-26a (tumor suppressors)) based on their diagnostic and prognostic values. This marker set could be explored in a multilevel or single unified assay for the diagnosis and prognosis of NPC. If carefully harnessed and standardized, it is hoped that the proposed marker set would help transform the diagnostic and prognostic realm of NPC, and ultimately, help prevent the life-threatening late-stage NPC disease.
\end{abstract}

Keywords: tumor-suppressor gene; oncogene; miRNA; nasopharyngeal carcinoma; tumor biomarker

\section{Introduction}

Nasopharyngeal carcinoma (NPC) is a malignant, undifferentiated squamous cell carcinoma, which is highly associated with latent infection of Epstein-Barr virus (EBV) [1]. EBV infection is highly prevalent; ubiquitously infecting people around the globe and mostly go asymptomatic [2]. Although NPC constitutes a major health burden in Southern China, Southeast Asia, the Arctic, and the Middle East/North Africa regions [3], to date, the exact cause of the disease is still unclear. However, high-risk factors that may contribute to NPC include EBV infection, dietary habits and lifestyle, cigarette smoking, exposure to environmental and occupational hazards, genetic predisposition (particularly chromosomal regions and genes), family history of NPC, and ethnicity [4].

The clinical presentation of NPC varies, ranging from unspecific epistaxis, auditory complaints, and unilateral nasal obstruction to cranial nerve palsies and nodal metastasis in the neck region $[5,6]$. Most people diagnosed with NPC are often at mid or late stages of the disease when symptoms are much obvious [7]. This underscores the need for early diagnosis. Sadly, the diagnosis of NPC at an 
early stage is quite challenging due to its deep location and lack of obvious clinical signs at an early stage [8]. Furthermore, there is no single laboratory blood test that provides a highly sensitive and specific result for the screening and diagnosis of NPC [9]. The consequence of poor test results cannot be overemphasized. Tests with low sensitivity could give rise to false-negative results, leading to missed diagnosis, and thus, promotion of disease progression. On the other hand, false-positive results can ensue from tests with low specificity, amounting to unnecessary nasoendoscopies, biopsy collection, and follow-up visits [9]. Even though the assessment of clinical symptoms and family history provides a good cue, nasopharyngeal endoscopy accompanied by histopathological examination of suspected lesions remains the gold standard method for NPC diagnosis [10]. However, this method is mainly applicable for suspected NPC patients and unsuitable for early diagnosis, especially in asymptomatic patients.

Given that tumorigenesis is a complex process stimulated by many factors, including environment (work hazard, physical exposure, microorganisms, etc.), genetics, and epigenetics [11], a multifaceted diagnostic approach may help address the challenges of early diagnosis. Notable mechanisms underlying tumorigenesis encompass epigenetic changes, genetic codes mutation, chromosome stability, DNA repair, and cell growth process (differentiation, apoptosis, movement, etc.) [12]. Deregulation of oncogenes and tumor suppressor genes (TSGs) stimulated by genetics and epigenetics is considered a driving force in the growth and progression of cancer [13]. For example, overexpression of c-Myc (an important oncogene) protein plays a role in the malfunctioning of several important cellular processes including cell growth control, proliferation, apoptosis, and cellular metabolism [14]. Similarly, the dysfunction of p53 (an important TSG) protein promotes cell propagation with serious DNA damage and implicated with interruption of cell cycle arrest and/or apoptosis (the p53-dependent apoptosis) [15]. However, in NPC, the oncogene-TSG regulatory relationship as it impacts tumorigenesis is not well understood. This is further compounded by the fact that EBV also expresses viral oncogenic genes (EBNA1 and LMP1) and miRNAs (BARTs and BHRF1) which can induce genetic mutations and epigenetic changes in host cells, consequently leading to tumorigenesis and progression of cancer [16]. Here, we summarize cellular and viral (EBV) protein and nonprotein coding oncogenic and tumor suppressor candidates, highlighting their potentials as diagnostic and prognostic tumor biomarkers in NPC (Figure 1).

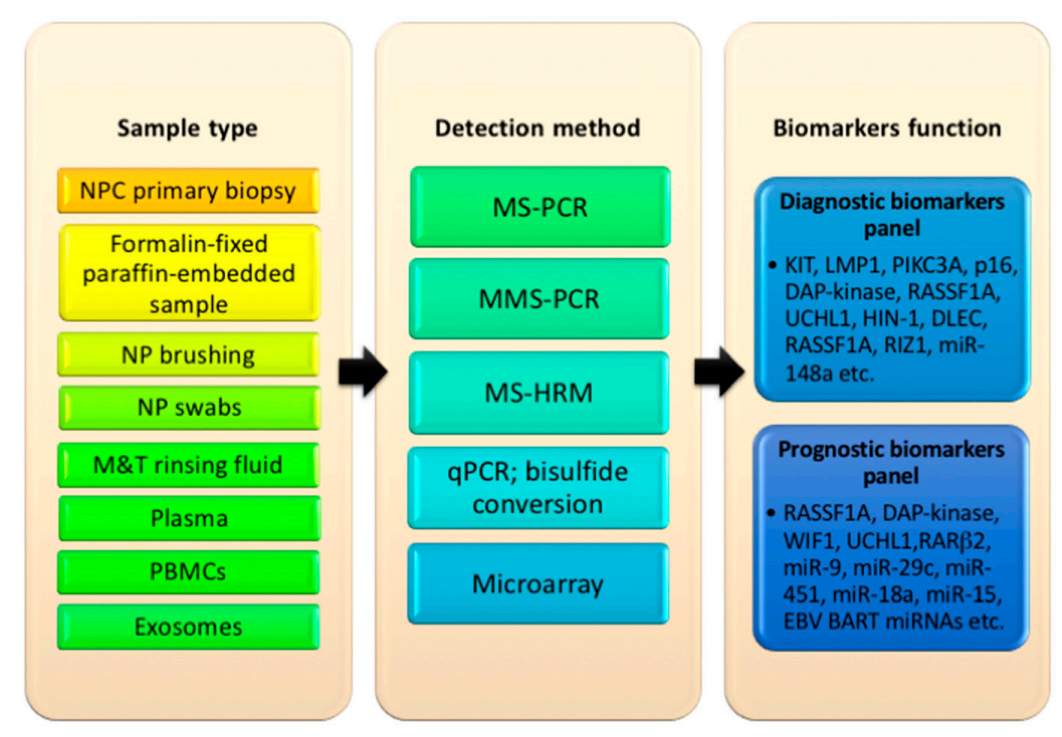

Figure 1. A summary of diagnostic and prognostic indications for the detection of nasopharyngeal carcinoma (NPC) using oncogenic and tumor suppressor biomarkers. NP: nasopharyngeal; M\&T: mouth and throat; PBMCs: peripheral blood mononuclear cells; MS-PCR: methylation-specific polymerase chain reaction (PCR); MMS-PCR: multiplex methylation-specific PCR; MS-HRM: methylation-sensitive high-resolution melting; qPCR: real-time PCR; EBV: Epstein-Barr virus. 


\section{Cellular Oncogenes Involved in NPC}

Oncogene mutations, which contribute to tumorigenesis, may serve as diagnostic and prognostic targets for NPC. However, oncogenic mutation patterns in NPC are not fully elucidated compared with other cancer types [17]. A study by Jiang et al. identified 24 hotspot mutations across 11 oncogenes (EGFR, CDK4, KIT, PDGFRA, KRAS, BRAF, MET, FGFR3, AKT1, PIK3CA, and NRAS) in NPC patients and found that KIT mutation was associated with poorer overall and relapse-free survival [17]. Similarly, Zhang et al. found positive mutations in eight oncogenes (PIK3CA, NRAS, KIT, PDGFRA, ABL, HRAS, EGFR, and BRAF) in NPC tumors. Interestingly, patients with these mutations tend to experience relapse or metastasis [18]. A study was conducted to screen targeted therapy-related oncogenic mutations in NPC using SNaPshot assay. Among 70 patients, 12 harbored mutations in five oncogenes (KIT, EGFR, PIK3CA, KRAS, EGFR/BRAF) with KIT mutation being the most prevalent. In addition, a patient was found to have dual oncogenic mutations (EGFR and BRAF). However, there was no association between the observed oncogenic mutations and tumor recurrence and metastasis [19]. Meanwhile, Chai et al. reported a significantly high level of FJX1 expression in primary NPC tissues, and the overexpression of FJX1 was associated with the promotion of cell proliferation, anchorage-dependent growth, and cellular invasion in vitro [20].

\section{EBV-Associated Oncogenes in NPC}

Apart from oncogenic mutations that occur in the human genome, the oncogenic human herpesvirus, EBV, is also closely associated with NPC development [1]. In the EBV genome, there are three potential NPC oncogenes-LMP1, LMP2, and BARF1 [21]. LMP1 is known as classical oncogenic protein and it is the main transforming protein of EBV [1]. LMP2 on the other hand can transform epithelial cells in vitro, while BARF1 is known for its oncogenic properties in NPC [22,23]. Hu et al. reported the expression of these putative oncogenes (LMP1, LMP2, and BARF1) in the majority of NPC samples compared with normal samples [21]. Wang et al. also reported the expression of LMP1 and BARF1 in tissue specimens of NPC patients and revealed an association between the expression of LMP1 and tumor-node-metastasis stage as well as lymph node metastasis [24]. However, in another study, the abundance of LMP1 protein is not correlated to the presence of lymph node or visceral metastasis or recurrence in north African NPC patients [25].

\section{Hypermethylation of TSGs Promoter in NPC}

Several studies have proposed that loss of heterozygosity (LOH) on chromosome 3p, 9p, 11q, and 13q regions are an early event for tumorigenesis in NPC [26-29]. LOH of the 3p chromosome region has been shown in about $95-100 \%$ of NPC cases and $75 \%$ of premalignant lesions [28]. These studies have suggested that aberrant hypermethylation at the promoter region of $\mathrm{CpG}$ islands and genetic alterations in chromosome underlie the development and progression of NPC. Furthermore, rising evidence reveals that multiple hypermethylated promoter regions are present in NPC epithelial cells (Table 1).

An attempt was made in the past to identify hypermethylation of p16 promoter in NPC using xenograft, cell line, and primary tumor [30]. Subsequently, few other studies were performed using methylation-specific polymerase chain reaction (MS-PCR) targeting p16. Approximately $23-66 \%$ of p16 methylation frequencies were recorded in primary undifferentiated NPC, followed by $46.4 \%$ in nasopharyngeal brushings and $42 \%$ in plasma [31-35]. A recent meta-analysis study has also suggested that p16 promoter hypermethylation significantly increases the risk of getting NPC in the future $[30,36]$. The results suggest that $\mathrm{p} 16$ promoter hypermethylation could be used as a potential diagnostic target for differentiating nonmalignant from malignant nasopharyngeal tumors. 
Table 1. Summary of hypermethylated tumor suppressor genes (TSGs) involved in NPC.

\begin{tabular}{|c|c|c|c|c|}
\hline TSG Biomarkers & Main Biological Function(s) & Method of Detection & Function of Biomarkers & Reference \\
\hline p16 & $\begin{array}{l}\text { Inhibitor of cyclin-dependent kinases (CDK) which } \\
\text { slows down the cell cycle by hindering progression from } \\
\text { G1 phase to S phase }\end{array}$ & MS-PCR & Diagnosis & [30-37] \\
\hline p15 & $\begin{array}{l}\text { Inhibits the growth of some kinds of tumor cells and acts } \\
\text { as a mediator of TGF- } \beta \text { induced cell arrest. p15 shares } \\
\text { extensive homology with p16 }\end{array}$ & MS-PCR & Diagnosis & {$[38,39]$} \\
\hline RASSF1A & $\begin{array}{c}\text { Regulates microtubule dynamics, cell cycle progression, } \\
\text { and apoptosis }\end{array}$ & MS-PCR & Diagnosis, prognosis & [38-42] \\
\hline DAP-kinase & $\begin{array}{l}\text { Activates in various cellular activities including } \\
\text { regulation of apoptosis, caspase-dependent death } \\
\text { programs, cytoskeletal dynamics, and immune functions }\end{array}$ & MS-PCR & Diagnosis & {$[32,35,38,43-45]$} \\
\hline $\mathrm{CDH} 1$ & $\begin{array}{l}\text { Involved in various mechanisms like regulating } \\
\text { cell-to-cell adhesions, mobility and proliferation of } \\
\text { epithelial cells especially E-cadherin protein }\end{array}$ & MS-PCR & Diagnosis & {$[31,39,46]$} \\
\hline E-cadherin & $\begin{array}{l}\text { Important mediators of cell-to-cell interactions in } \\
\text { epithelial tissues and holds cells together }\end{array}$ & MS-PCR & Diagnosis & {$[38,47]$} \\
\hline HIN-1 & Inhibitor for cell growth, invasion, and AKT1 activation & MS-PCR & Diagnosis & [48] \\
\hline MGMT & $\begin{array}{l}\text { Has the ability to stoichiometrically repair DNA adducts } \\
\text { and to self-inactivate }\end{array}$ & MS-PCR & Diagnosis & [39] \\
\hline MLH1 & $\begin{array}{l}\text { Provides instructions for making a protein which plays } \\
\text { an important role in DNA repairs by fixing errors during } \\
\text { DNA replication in preparation for cell division }\end{array}$ & MS-PCR & Diagnosis & [39] \\
\hline RIZ1 & Induces G2-M cell cycle arrest and/or apoptosis & MS-PCR & Diagnosis & {$[44,49]$} \\
\hline DLEC1 & $\begin{array}{l}\text { Suppresses tumor growth and reduces the invasiveness } \\
\text { of cancer cells }\end{array}$ & MS-PCR & Diagnosis & [32] \\
\hline UCHL1 & $\begin{array}{l}\text { Provides instructions for making ubiquitin } \\
\text { carboxyl-terminal esterase L1 enzyme which is involved } \\
\text { in cell machinery that degrades unwanted proteins }\end{array}$ & MS-PCR & Diagnosis & {$[32,42]$} \\
\hline WIF1 & $\begin{array}{l}\text { A lipid-binding protein which binds to Wnt proteins and } \\
\text { prevents them from triggering signaling pathways }\end{array}$ & MS-PCR & Diagnosis, prognosis & {$[42,44,49]$} \\
\hline DLC1 & $\begin{array}{l}\text { Has the ability to enhance activated GTP-bound } \\
\text { Rho-GTPases' intrinsic ability to convert their GTP into } \\
\text { GDP, thus rendering them inactive }\end{array}$ & MS-PCR & Diagnosis & [49] \\
\hline SOX11 & $\begin{array}{l}\text { Regulates embryonic development and determines the } \\
\text { cell's fate }\end{array}$ & MS-PCR & Diagnosis, prognosis & [50] \\
\hline 14-3-3 sigma & $\begin{array}{l}\text { Act as a negative regulator in the cell cycle and has been } \\
\text { identified as p53-inducible gene product involved in cell } \\
\text { cycle checkpoint control after DNA damage }\end{array}$ & MS-PCR & Prognosis & [51] \\
\hline
\end{tabular}
MS-PCR; methylation-specific polymerase chain reaction.

Hypermethylation of Ras Association Domain Family 1A (RASSF1A) promoter is another potential biomarker for early detection of NPC. Several reports showed that the methylation frequency of RASSF1A promoters can be as high as $46-91 \%$ in primary tumors, $39.3 \%$ in nasopharyngeal brushings, $33 \%$ in nasopharyngeal swabs, and 37\% in mouth and throat-rinsing fluid [38-41]. Similar cases have been observed in Death-associated Protein Kinase (DAP-kinase) promoter hypermethylation where the methylation frequency of DAP-kinase promoters was as high as $75-77 \%$ in NPC primary tumors, $63 \%$ in nasopharyngeal swabs, $50 \%$ in both nasopharyngeal brushing and mouth and throat-rinsing fluid and $20 \%$ in plasma sample $[35,38,43]$.

Other known TSGs promoter hypermethylation in NPC include DAPK1, DLEC1, CDKN2A, E-cadherin, p15, WIF1, UCHL1, PTEN, etc., which can be used as alternative surrogate markers for early NPC diagnosis. Nevertheless, a single epigenetic change is not sufficiently sensitive and accurate for early detection of NPC especially in tissue biopsies or body fluids. This is because patients are less likely to have the same TSG hypermethylation profile. Therefore, focusing on single epigenetic changes can lead to false-negative results in diagnosis. Thus, evaluating multiple specific gene methylation profiles have been suggested to improve the sensitivity of NPC diagnosis [44]. Nawaz et al. utilized multiplex methylation-specific PCR (MMSP) to screen 10 potential TSG markers for NPC diagnosis, including two markers from EBV. The study found that combined analyses of 10 methylation markers (RASSF1A, DAPK, ITGA9, p16, WNT7A, CHFR, CYB5R2, WIF1, RIZ1, FSTL1) and two EBV markers (EBNA1 and LMP1) provided good discrimination between NPC and NPC control tissues with a detection rate of $91 \%$ in biopsies with $90 \%$ specificity [44]. Another study that targeted the methylation 
of four TSGs (RASSF1A, WIF1, DAPK1, and RARß2) alongside EBV DNA markers showed significant detection of NPC at all stages as well as local recurrence [45].

It has been demonstrated that the combination of four methylation gene markers (CDKN2A, DLEC1, DAPK1, and UCHL1) can be employed for the prediction of early NPC [32]. Furthermore, the combination of RASSF1A and p16 methylation markers give good discrimination between NPC and non-NPC samples, although better results could be obtained by combining five methylation markers (RASSF1A, p16, WIF1, CHFR, and RIZ1) [49]. The identification of multiple methylated TSGs has also been utilized as a prognostic cue in NPC. A study that investigated a panel of six hypermethylated genes (WIF1, UCHL1, RASSF1A, CCNA1, TP73, and SFRP1) in NPC revealed that high methylation level is associated with poor disease-free survival [42]. Overall, these data support the utilization of some specific hypermethylated TSGs as key indicators of NPC and could be targeted in the prediction, diagnosis, and prognosis of the disease.

\section{Noncoding RNAs in NPC}

The oncogenic and tumor-suppressive roles of noncoding RNA (ncRNA), especially the regulatory ncRNAs, have been explored in a vast majority of cancers. Many are now considered useful diagnostic, prognostic, and therapeutic biomarkers of cancers. NcRNAs (including short and long ncRNAs) have also been implicated in NPC. Widely studied and noteworthy ncRNA biomarkers mostly implicated in NPC include miRNA and long noncoding RNAs (lncRNAs). Others like small nucleolar RNA (SnoRNA), small interfering RNA (siRNA), Y RNA, etc., are rarely implicated in NPC. For instance, dysregulation in several SnoRNAs (e.g., snoRA21, snoRA23, snRD112-114, snoRD33, snoRD5, etc.) have been associated with many types of cancers including breast cancer, hepatocellular carcinoma, colorectal cancer, prostate cancer, acute promyelocytic leukemia, among others (reviewed in [52] and [53]), however, there is much quiescence regarding their role in NPC. Furthermore, only a few recent studies have demonstrated the upregulation of lncRNA small nucleolar RNA host genes (SNHGs) such as SNHG5 [54], SNHG7 [55,56], SNHG12 [57] and SNHG20 [58] in the blood and tissue samples of NPC patients. Thus, we focused on miRNA and long noncoding RNA for which there is more evidence to support the prognostic and diagnostic potentials in NPC, particularly using human subjects.

\subsection{MicroRNA (miRNA or miR) in NPC}

Although microRNAs (miRNAs) are known to be involved in the regulation of the cellular process, studies suggest that they may be associated with the manifestation of cancer [59]. MiRNAs also consist of tumor suppressor miRNAs and oncogenic miRNAs (onco-miRNAs). The loss-of-function of tumor suppressor miRNAs and gain-of-function of onco-miRNAs appears to enhance the formation of cancer [59]. The most common tumor suppressor miRNAs involved in NPC are miR-9, miR-26a, miR-29c, miR-200 family, and Let-7 family. The overexpression of onco-miRNAs miR-141, miR-214, miR-18a/b, miR-155, and miR-21 have also been identified in NPC [60-62] (Table 2).

Table 2. Summary of tumor suppressor miRNAs and onco-miRNAs involved in NPC.

\begin{tabular}{cccc}
\hline MiRNAS (Biomarkers) & Main Biological Function(s) & Validated Targets in NPC & Prognostic Association \\
\hline miR-9 & $\begin{array}{c}\text { Tumor Suppressor MiRNAs } \\
\text { Regulates cell proliferation, migration, invasion, } \\
\text { epithelial-mesenchymal transition (EMT), metastasis, } \\
\text { apoptosis, and tumor angiogenesis }\end{array}$ & CXCR4 [63] & Negative \\
\hline miR-26a & Suppress cell proliferation and colony formation & EZH2 [64,65], c-Myc [61] & - \\
\hline miR-29c & $\begin{array}{c}\text { Inhibits cell migration and invasion, metastasis, associated } \\
\text { with chemoresistance and radioresistance }\end{array}$ & $\begin{array}{c}\text { TIAM1 [66], MCL-1 [67], } \\
\text { BCL-2 [67] }\end{array}$ & Negative \\
\hline miR-200 family & Regulates cell proliferation, migration, invasion, and EMT & ZEB2 [68], CTNNB1 [68] & - \\
\hline Let-7 family & Inhibits cell proliferation and induces cell apoptosis & c-Myc [69], HMG2A [70] & Foxq1 [71] \\
\hline miR-124 & Inhibits cell growth, migration, and invasion & - & - \\
\hline
\end{tabular}


Table 2. Cont.

\begin{tabular}{|c|c|c|c|}
\hline MiRNAS (Biomarkers) & Main Biological Function(s) & Validated Targets in NPC & Prognostic Association \\
\hline miR-451 & Regulates cell proliferation, invasion and predicts outcome & MIF [72] & Negative \\
\hline $\mathrm{miR}-216 \mathrm{~b}$ & Suppress cell proliferation and invasion & PKCa [73], K-Ras [74] & - \\
\hline miR-98 & Suppress NPC relapse and predicts recurrence & EZH2 [65] & Negative \\
\hline miR-375 & Suppress NPC relapse and predicts recurrence & Metadherin [75] & Negative \\
\hline \multicolumn{4}{|c|}{ Onco-miRNAs } \\
\hline $\operatorname{miR}-21$ & $\begin{array}{l}\text { Promotes cell proliferation and migration and high expression } \\
\text { resulting in chemoresistance }\end{array}$ & $\begin{array}{c}\text { PTEN/AKT [76], PDCD4 } \\
\text { [76], TPM1, SPRY [76], ERCK } \\
\text { [76], Bcl-2 [60] }\end{array}$ & Positive \\
\hline miR-18a & $\begin{array}{l}\text { Lymph node metastasis, overall downregulation of miRNA } \\
\text { expression }\end{array}$ & $\begin{array}{c}\text { Dicer1 [77], c-Jun and c-Myc } \\
\text { [77] }\end{array}$ & Positive \\
\hline miR-18b & Promotes cell proliferation & CTGF [78], & - \\
\hline miR-141 & $\begin{array}{l}\text { Promotes cell proliferation, migration, invasion, and cell } \\
\text { apoptosis }\end{array}$ & $\begin{array}{l}\text { BRD3 [79], PTEN [79], } \\
\text { SPLUNC1 [79], UBAP1 [79] }\end{array}$ & - \\
\hline miR-214 & Promotes cell proliferation, invasion, and metastasis & Lactotransferrin [80] & - \\
\hline miR-30a & Increase cell capability of metastasis and invasion & E-cadherin [81] & - \\
\hline miR-149 & Promotes cell migration, EMT, and invasion & E-cadherin [82] & - \\
\hline miR-155 & $\begin{array}{l}\text { Promotes cell proliferation, migration, invasion, colony } \\
\text { formation, invasion, prognostic for tumor stage and predicts } \\
\text { outcome }\end{array}$ & JMJD1A [83], BACH1 [83] & Positive \\
\hline miR-504 & Predicts radioresistance outcome & NRF1 [84] & Positive \\
\hline $\begin{array}{c}\text { EBV-encoded BART } \\
\text { miRNAs such as BART } \\
\text { 1-3p, 5p, BART5, BART } \\
6-5 p, \text { BART 7, BART 3, -6, } \\
-8,-16,-22\end{array}$ & $\begin{array}{l}\text { Promotes tumor metastasis, cellular growth, and proliferation, } \\
\text { inhibit cell apoptosis, and maintain virus latency }\end{array}$ & $\begin{array}{c}\text { PTEN [85], PUMA [85], } \\
\text { DICE1 [85], E-cadherin [85], } \\
\text { Dicer [85], C-myc, and C-jun } \\
\text { [85] }\end{array}$ & Positive \\
\hline
\end{tabular}

Tumor suppressor miR-9 is one of the most implicated miRNAs in NPC [62]. The miR-9 functions to regulate essential cellular processes (proliferation, migration, apoptosis, etc.), metastasis, angiogenesis, and it is involved in epithelial-mesenchymal transition (EMT) through binding to the $3^{\prime}$-UTR of CXCR4 receptor to downregulate its expression [63]. However, the miR-9 expression in NPC is commonly downregulated, and low-level expressions of miR-9 in plasma are significantly associated with increased lymphatic invasion, aggressive phenotypes, advanced NPC stage, and poor survival rates [86]. Most importantly, miR-9 could be an independent prognostic biomarker for NPC metastasis stage as its high expression is correlated with decreased proliferation, migration and invasion in NPC cells, and low expression correlated with advanced NPC stage [87]. Onco-miRNA miR-18a/b on the other hand is a member of the oncogenic miR-17-92 cluster which plays a role in NPC development. MiR-18a is indeed upregulated in NPC samples and correlates with advanced NPC stages, metastasis in the lymph node, EBV infection, and higher mortality rates [61]. Meanwhile, miR-18b directly suppresses connective tissue growth factor (CTGF) expression in NPC which leads to NPC progression and poor prognosis due to the downregulation of CTGF [78].

Again, a single miRNA marker is not sufficiently sensitive and precise for prognosis or early detection of NPC due to the possibility of different miRNA profiles among patients. Thus, investigating multiple miRNA biomarker profiles would be beneficial to improve the sensitivity of NPC diagnosis and prognosis. It is important to note that circulating miRNAs have been identified as potential noninvasive biomarkers for diagnosis and prognosis in multiple cancers due to their remarkable stability in the blood [88]. A recent study that analyzed the changes in plasma miRNAs before and after treatment of NPC showed that miR-9-3p, miR-124-3p, miR-892b, and miR-3676-3p were expressively upregulated after treatment compared with pretreatment, and downregulated at recurrence phase or metastasis [86], highlighting the potential of miRNAs as biomarkers for monitoring recurrence and metastasis in NPC patients. In another study, it was found that four miRNAs (miR-17, miR-20a, miR-29c, and miR-223) were expressed differentially in the serum of NPC patients compared with noncancerous control [89]. Furthermore, a study advanced the combination of four serum miRNAs 
(miR-22, miR-572, miR-638, and miR-1234) as a potent miRNA signature to categorize high- and low-risk groups of NPC patients in terms of overall survival and distant metastasis-free survival [90].

After its discovery in 2001, miR-21 has been reported as associated with the development of cancer. It is, in addition, one of the most studied miRNAs in human cancers [76]. MiRNA-21 expression is also substantially increased in many cancers and may play a critical role in cancer cell survival, invasion, and apoptosis [76,91]. Recent findings suggest that miR-21 induced the expression of a significant number of cancer-related genes such as PDCD4, PTEN, SPRY, ERCK, TPM1, and Bcl-2, and responsible for regulating lymphocyte function [76,92]. MiR-21 inhibitors have shown suppression of NPC cell proliferation and migration by Bcl-2 downregulation [60]. The upregulation of circulating miR-21 may increase the chemoresistance of NPC cells to cisplatin and thus be associated with poor NPC prognosis [91]. The above studies bolster the assertion that loss-of-function of tumor suppressor miRNAs and gain-of-function of onco-miRNAs can be ascribed to NPC progression, advanced NPC stage, and poor survival rates.

\subsection{EBV-Encoded BART miRNAs in NPC}

Like cellular miRNA, studies have shown that EBV miRNAs may also be connected with the development of NPC [93]. Ye et al. demonstrated that EBV-miR-BARTs play a role in modulating metabolism-associated gene expression in NPC cells [94]. Expression of EBV-BART miRNAs in NPC contributes to numerous effects, including virus latency (BART2, BART6-5p), cell growth and proliferation (BART3, BART9, BART10, BART7, BART8), cell apoptosis (BART 1-5p, 16, 17-5p, BART cluster 1, BART5, BART20), as well as tumor metastasis and recurrence (BART1, BART7, BART9) [85].

The characterization of EBV miRNA transcriptome of clinical NPC tissues showed that most of the high copies of EBV miRNAs share seed sequences (2-7 nucleotides) with human miRNAs, suggesting that the content of seed sequence may be significant reason underlying the accumulation of EBV-encoded proteins, BART miRNAs [95]. Gourzones et al. found that miR-BART17 is significantly more abundant in plasma samples of NPC patients with a sensitivity of $77 \%$ and up to $90 \%$ specificity. Interestingly, they found a marked increase of miR-BART17 accompanied by an increase in tumor mass in one patient, suggesting that the concentration of miR-BART17 in plasma may be associated with NPC progression [96]. In addition, another study found that miR-BART7 is significantly higher in NPC patients and also enhanced proliferation, migration, and invasion of NPC cells in vitro [97]. Thus, miR-BART7 may be useful as a novel prognostic serological biomarker for predicting NPC treatment efficacy [98].

\subsection{Long Noncoding RNAs (lncRNAs) in NPC}

LncRNAs display oncogenic and tumor suppressor characteristics with varying tissue- or cell-specific gene expression profiles. LINC00312-NAG7 is one of the first lncRNAs studied and functions as a tumor suppressor gene in NPC [99]. LINC00312-NAG7 acts to reduce the spread of NPC cells and prevent the progression from G1 to S phase in the cell cycle, thus aggravating cell apoptosis. The LINC00312-NAG7 expression is negatively correlated with tumor size but positively correlated with lymph node metastasis [100]. LINC00312-NAG7 is also highly negatively associated with EBV-encoded noncoding RNA and EBER1 in NPC. However, LINC00312-NAG7 expression could be used to distinguish NPC and noncancerous cells [100].

LncRNA LINC01133 in chromosome 1q23.2 has been shown to be downregulated in colorectal cancer, gastric cancer, oral squamous cell carcinoma, and NPC [101-104]. In NPC, LINC01133 has been shown to inhibit cell proliferation, invasion, and migration, both in vitro and in vivo. LINC01133 was indicated to have tumor suppressor function in NPC as its expression was lower in NPC samples $(n=31)$ compared to normal samples $(n=10)$ [101]. On the other hand, LncRNA Plasmacytoma variant translocation 1 (PVT1) is an oncogene which shows higher expression in NPC cells than normal nasopharyngeal epithelial tissue $(64 \%, 60 / 94$ vs. $18 \%, 6 / 33 ; p<0.001)$, and higher expression of PVT1 
resulted in worse progression-free survival $(p=0.0028)$ and overall survival $(p=0.0006)$ [105]. Thus, these biomarkers could be useful diagnostic and prognostic indicators of NPC.

Other known oncogenic IncRNAs involved in NPC include HOTTIP, HOTAIR, ROR, XIST, HNF1A-AS, DRAIC, NPCCAT1, ANRIL, H19, LINC01385, LINC01503, CASC15, PXN-AS1-L, LINC00460, and UCA1, which involve in increasing cell proliferation, migration, invasion, and metastasis [106-120]. High expressions of LINC00319, LINC01503, HOTTIP, PXN-AS1-L, ANRIL, HOTAIR, LINC01385, and XIST are associated with poor prognosis and short overall survival in NPC $[106,107,109,113,115,117,120,121]$. LncRNAs, LINC00346, and ROR play a critical functional role in chemoresistance, particularly cisplastin therapy [108,122], while MALAT1, PVT1, and NEAT1 play a major role in radioresistance $[105,123,124]$ (Table 3).

Table 3. Summary of tumor suppressor lncRNAs and onco-lncRNAs involved in NPC.

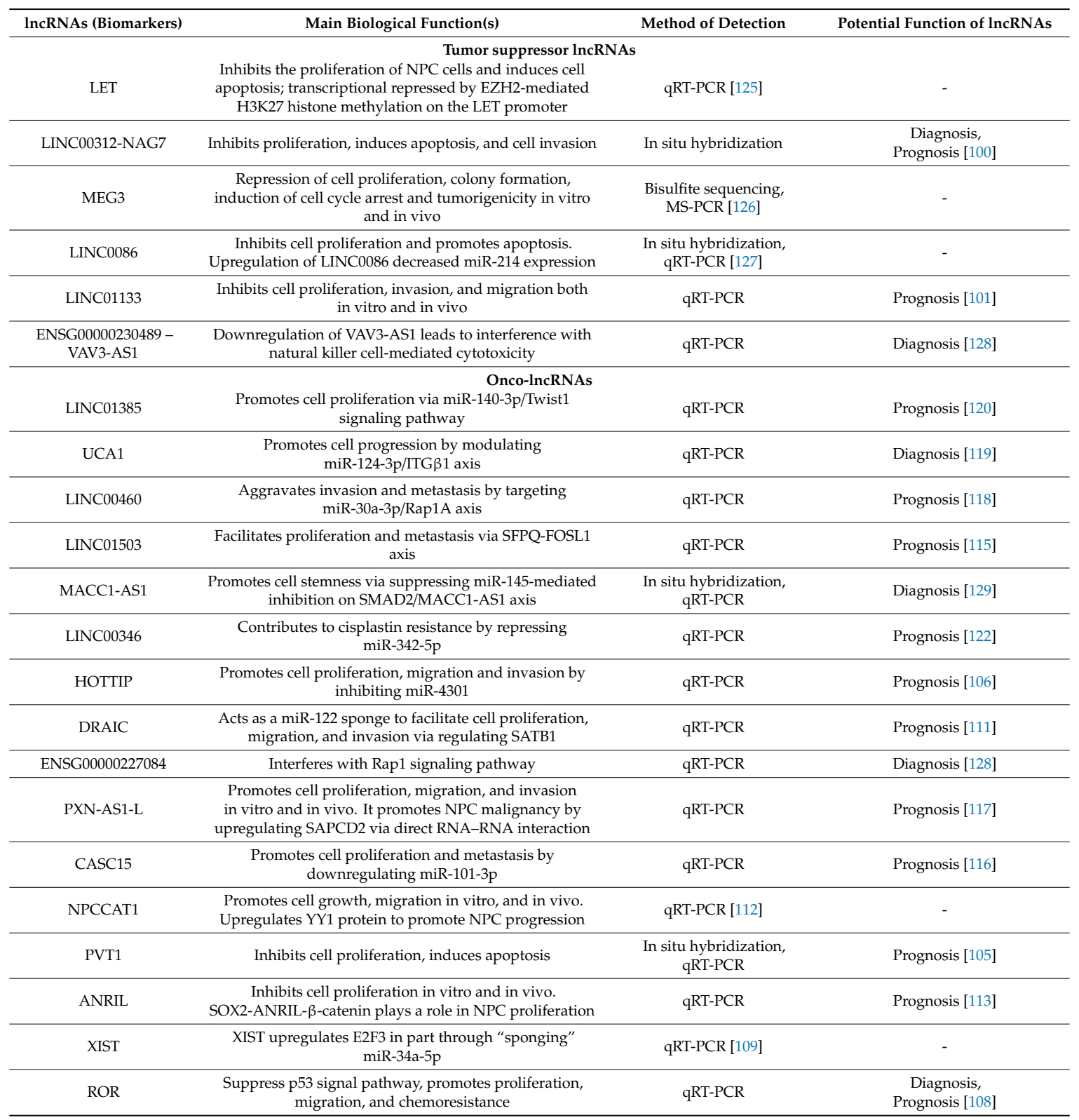


Table 3. Cont

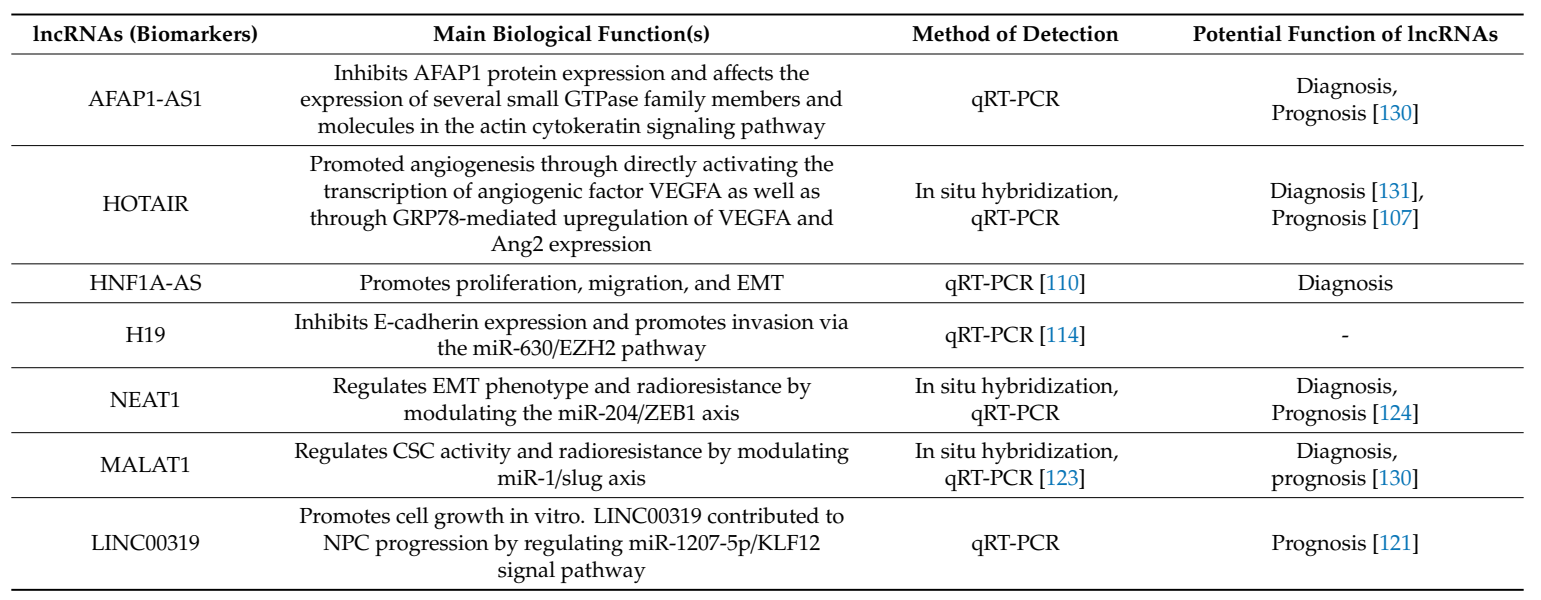

MS-PCR; methylation-specific polymerase chain reaction, qRT-PCR; reverse transcriptase real-time polymerase chain reaction.

\subsection{EBV-Encoded BART IncRNAs in NPC}

Like cellular lncRNAs, studies have shown that EBV lncRNAs may also be associated with NPC development owing to their varied expressions in EBV-infected cells, exosomes, and EBV-associated cancers. A study showed that EBV-miR-BART6-3p can directly target and downregulate lncRNA LOC553103 [132]. Furthermore, overexpression of lncRNA LOC553103 can promote tumor spread, invasion, mesenchymal transition, and metastasis in vitro and in vivo [132]. BC200, LINC00672, and LINC00982 expression profiles have been shown to be linked to EBV-associated epithelial cancer cells, like NPC [133]. The findings showed substantial upregulation of BC200 and LINC00672 in EBV-infected 293 cells while LINC00982 was downregulated [133].

\section{Types of Sample Used to Detect Oncogenes, Promoter Hypermethylation, and miRNAs in NPC}

Currently, NPC diagnosis relies largely on the tissue-sampling method via endoscopic biopsy of suspected tumor sites. This rather invasive method is not suitable for the early detection of NPC. The need to explore liquid biopsies from peripheral blood (plasma/serum/peripheral blood mononuclear cells (PBMCs)/exosomes) is paramount since they also carry certain tumor biomarkers. Furthermore, liquid biopsy possesses remarkable benefits over the traditional solid biological tissue sampling; it has low risk, it is noninvasive and nearly painless, no surgery is required, and it reduces the cost and time of diagnosis [134]. In addition, nasopharyngeal brushing, nasopharyngeal swabs, and throat-rinsing fluids can also be used in NPC diagnosis due to their noninvasiveness and convenient tissue-sampling method rather than conventional tissue-sampling method [135]. However, the frequency of NPC biomarkers may vary in different sample types. We provide a summary of the major types of samples used in detecting oncogenes and tumor suppressors in NPC (Table 4) to ease and enhance decision on sample selection for future NPC studies. 
Table 4. Major samples used in detecting promising NPC biomarkers.

\begin{tabular}{|c|c|c|}
\hline Type of Samples & Frequency of Oncogenes Involved (\%) & Frequency of Tumor Suppressors Involved (\%) \\
\hline NPC primary biopsy & $\begin{array}{c}\text { EBV-LMP1 (62.5\%) [24] } \\
\text { EBV-BARF1 (13.3\%) [24] } \\
\text { miR-141 [136] } \\
\text { lncRNA PVT1 (64\%) [105] } \\
\text { lncRNA NPCCAT1 [112] } \\
\text { lncRNA CASC15 [116] } \\
\text { lncRNA PXN-AS1-L [117] } \\
\text { lncRNA HOTTIP [106] } \\
\text { lncRNA LINC00346 [122] } \\
\text { lncRNA LINC01503 [115] } \\
\text { lncRNA LINC00460 [118] } \\
\text { lncRNA UCA1 [119] } \\
\text { lncRNA ANRIL [113] } \\
\text { lncRNA H19 [114] } \\
\text { lncRNA MALAT1 [123] } \\
\text { lncRNA NEAT1 [124] } \\
\text { lncRNA LINC01385 [120] } \\
\text { lncRNA HNF1A-AS [110] }\end{array}$ & $\begin{array}{c}\text { p16 }(23-66 \%)[32-34] \\
\text { p15 }(50-80 \%)[38,39] \\
\text { RASSF1A }(46-67 \%)[38,39] \\
\text { DAP-kinase }(75-77 \%)[38,43] \\
\text { RIZ1 }(60 \%)[137] \\
\text { CDH1 }(50 \%)[39,46] \\
\text { E-cadherin }(52-65 \%)[38,46] \\
\text { HIN-1 }(77 \%)[48] \\
\text { MGMT }(28 \%)[39] \\
\text { MLH1 }(40 \%)[39] \\
\text { DLC1 (79\%) [138] } \\
\text { SOX11 }(67.4 \%)[50] \\
\text { 14-3-3 sigma (84\%) [51] } \\
\text { PTEN (82.2\%) [139] } \\
\text { miR-9 [140] } \\
\text { lncRNA LINC00312-NAG7 (51.4\%) [100] }\end{array}$ \\
\hline Formalin-fixed paraffin-embedded sample & $\begin{array}{c}\text { ABL1 }(1.6 \%)^{*} \\
\text { AKT1 }(0 \%)^{*} \\
\text { AKT2 }(0 \%)^{*} \\
\text { BRAF }(0.8 \%)^{*} \\
\text { CDK }(0 \%)^{*} \\
\text { EGFR }(0.8 \%)^{*} \\
\text { ERBB2 }(0 \%)^{*} \\
\text { FGFR1 }(0 \%)^{*} \\
\text { FGFR3 }(0 \%)^{*} \\
\text { FLT3 }(0 \%)^{*} \\
\text { HRAS }(0.8 \%)^{*} \\
\text { JAK2 }(0 \%)^{*} \\
\text { KIT }(3.3-33 \%)[18,141] \\
\text { KRAS }(0 \%)^{*} \\
\text { MET }(0 \%)^{*} \\
\text { NRAS }(4.1 \%)^{*} \\
\text { PDGFRA }(1.6 \%)^{*} \\
\text { PIKC3A }(4.9-62.96 \%)[18,142] \\
\text { RET }(0 \%)^{*} \\
\text { ROCK1 }(28.4 \%)[142] \\
\text { EBV-miR-BART8-3p (52\%) [143] } \\
\text { miR-3182 }(51 \%)[143] \\
\text { miR-18a }(71.1 \%)[144] \\
\text { miR-149 }(82.4 \%)^{* *} \\
\text { miR-141 }(52.9 \%)^{* *} \\
\text { miR-205 }(94.1 \%)^{* *} \\
\text { miR-196a }(88.2 \%)^{* *} \\
\text { miR-149 }(82.4 \%)^{* *} \\
\text { miR-183 }(64.7 \%)^{* *} \\
\text { miR-224 }(58.8 \%)^{* *} \\
\text { miR-210 }(58.8 \%)^{* *} \\
\text { miR-136 }(47.1 \%)^{* *} \\
\text { miR-200c }(64.7 \%)^{* *} \\
\text { lncRNA MACC1-AS1 [129] } \\
\text { lncRNA HOTAIR [107] }\end{array}$ & $\begin{array}{c}\text { p16 (5\%) [145] } \\
\text { miR-150 (82.4\%) ** }\end{array}$ \\
\hline NP brushing & $\begin{array}{c}\text { BARF1 [146] } \\
\text { EBV-miR-BART1-5p [147] } \\
\text { EBV-miR-BART5 [147] } \\
\text { EBV-miR-BART6-5p [147] } \\
\text { EBV-miR-BART17-5p [147] }\end{array}$ & $\begin{array}{c}\text { WIF1 }(61.2 \%)[49] \\
\text { p16 }(46.4-66 \%)[35,49] \\
\text { RASSF1A }(39.3-75.5 \%)[35,49] \\
\text { DAP-kinase }(79.2 \%)[49] \\
\text { RIZ1 }(56.6 \%)[49] \\
\text { DLC1 }(76.9 \%)[49]\end{array}$ \\
\hline NP swabs & LMP1 [148] & $\begin{array}{c}\text { p16 }(17 \%)[38] \\
\text { RIZ1 (37\%) [137] } \\
\text { E-cadherin (27\%) [38] }\end{array}$ \\
\hline M\&T rinsing fluid & - & $\begin{array}{c}\text { p16 (17\%) [38] } \\
\text { RIZ1 (30\%) [137] } \\
\text { E-cadherin }(43 \%) \text { [38] }\end{array}$ \\
\hline Plasma & $\begin{array}{c}\text { EBV-miR-BART7 [98] } \\
\text { EBV-miR-BART13 [98] } \\
\text { miR-21 [60] }\end{array}$ & $\begin{array}{c}\text { p16 }(42 \%)[31] \\
\text { RIZ1 }(23 \%)[137] \\
\text { miR-9 [87] }\end{array}$ \\
\hline PBMCs & $\begin{array}{l}\text { PIKC3A [149] } \\
\text { TP53 [149] }\end{array}$ & RIZ1 (10\%) [137] \\
\hline Exosomes & $\begin{array}{l}\text { HIF1 } \alpha[150] \\
\text { LMP1 [151] }\end{array}$ & $\begin{array}{c}\text { DLEC1 }(25 \%) \\
\text { UCHL1 }(64.9 \%) \\
\text { miR-9 [152] }\end{array}$ \\
\hline
\end{tabular}

${ }^{*}$ Data from reference [18] ${ }^{* *}$ Data from reference [153]. 


\section{Proposed Selection of Oncogene-Tumor Suppressor Biomarkers for Diagnosis and Prognosis in NPC}

As delineated above, there are several potential oncogenes and tumor suppressors that could be further explored to develop a less invasive and dependable diagnostic assay for the early detection of NPC. Because the use of a single biomarker has been shown to be unreliable for the detection and prognosis of NPC, we recommend a multilevel screening or the development of an assay that would encompass these main identified biomarker domains (oncogene and tumor suppressors) to enhance better specificity in the detection of NPC. Based on the frequencies and diagnostic values demonstrated, we propose here a 10-biomarker panel for the duo: KIT, LMP1, PIKC3A, miR-141, and miR-18a/b (oncogenic biomarkers) and p16, RASSF1A, DAP-kinase, miR-9 and miR-26a (tumor suppressors). It is hoped that these biomarkers, if properly harnessed and standardized, would enable a more conclusive and dependable NPC diagnosis. If carefully exploited, we strongly believe they can as well serve as potent indicators in the prognosis and determination of the metastatic stage of NPC.

Methods that could be used for the detection of tumor biomarkers include methylation-specific PCR, multiplex methylation-specific PCR, methylation-sensitive high-resolution melting, real-time quantitative PCR after bisulfide conversion, and microarray assays [15,16,29,32,35,53]. However, these methods favor the selection of only a few markers. Thus, our proposed streamlined biomarker set can be better investigated. In any case, to assess the diagnostic strength of these select biomarkers, it is imperative to measure the result against the gold standard detection method to establish reliability. In addition to this, the biomarker profile must be assessed before and after treatment for the evaluation of prognostic potential. Finally, large scale studies using different sample types would be required for the validation of these NPC biomarker sets.

\section{Conclusions}

NPC is a disease whose exact cause remains largely unknown. Its developmental process is complex and has been attributed to genetics and epigenetics, as well as biological and environmental factors (e.g., work hazard, physical exposure, microorganisms, etc.). In this review, oncogenes, tumor suppressor genes, and microRNA of diagnostic and prognostic potentials in NPC were discussed. Furthermore, we proposed a 10-biomarker set (KIT, LMP1, PIKC3A, miR-141, and miR-18a/b (oncogenic biomarkers) and p16, RASSF1A, DAP-kinase, miR-9, and miR-26a (tumor suppressors)) that could be focused upon and further explored in future studies. It is hoped that these select biomarkers would enhance the development of a reliable diagnostic and prognostic NPC tool.

Author Contributions: Conceptualization, E.N.S.E.A.R., A.A.I., and C.Y.Y.; validation, E.N.S.E.A.R. and A.A.I.; writing - original draft preparation, E.N.S.E.A.R. and A.A.I; writing-review and editing, E.N.S.E.A.R., A.A.I., and C.Y.Y. All authors have read and agreed to the published version of the manuscript.

Funding: This research was funded by the Ministry of Higher Education Malaysia (MOHE) through Fundamental Research Grant Scheme (FRGS, 203/PPSP/6171209).

Acknowledgments: The first (E.N.S.E.A.R.) and second (A.A.I.) authors are financially supported by Universiti Sains Malaysia via USM Fellowship Scheme.

Conflicts of Interest: All the authors have declared that there is no conflict of interest regarding the publication of this paper. The funders had no role in the design of the study; in the collection, analyses, or interpretation of data; in the writing of the manuscript, or in the decision to publish the results.

\section{References}

1. Young, L.S.; Dawson, C.W. Epstein-Barr virus and nasopharyngeal carcinoma. Chin. J. Cancer 2014, 33, 581-590. [CrossRef] [PubMed]

2. IARC Working Group on the Evaluation of Carcinogenic Risk to Humans. Epstein-Barr Virus and Kaposi's Sarcoma Herpesvirus/Human Herpesvirus 8; International Agency for Research on Cancer: Lyon, France, 1997.

3. Chang, E.T.; Adami, H.-O. The Enigmatic Epidemiology of Nasopharyngeal Carcinoma. Cancer Epidemiol. Biomark. Amp. Prev. 2006, 15, 1765. [CrossRef] [PubMed] 
4. Wu, L.; Li, C.; Pan, L. Nasopharyngeal carcinoma: A review of current updates. Exp. Ther. Med. 2018, 15, 3687-3692. [CrossRef] [PubMed]

5. Sireci, F.; Speciale, R.; Sorrentino, R.; Turri-Zanoni, M.; Nicolotti, M.; Canevari, F.R. Nasal packing in sphenopalatine artery bleeding: Therapeutic or harmful? Eur. Arch. Oto-Rhino-Laryngol. 2017, 274, 1501-1505. [CrossRef] [PubMed]

6. Chua, M.L.K.; Wee, J.T.S.; Hui, E.P.; Chan, A.T.C. Nasopharyngeal carcinoma. Lancet 2016, 387, $1012-1024$. [CrossRef]

7. Wang, K.H.; Austin, S.A.; Chen, S.H.; Sonne, D.C.; Gurushanthaiah, D. Nasopharyngeal Carcinoma Diagnostic Challenge in a Nonendemic Setting: Our Experience with 101 Patients. Perm. J. 2017, 21, 16-180. [CrossRef]

8. Tabuchi, K.; Nakayama, M.; Nishimura, B.; Hayashi, K.; Hara, A. Early detection of nasopharyngeal carcinoma. Int. J. Otolaryngol. 2011, 2011, 638058. [CrossRef]

9. Tay, J.K.; Lim, M.Y.; Kanagalingam, J. Screening in Nasopharyngeal Carcinoma: Current Strategies and Future Directions. Curr. Otorhinolaryngol. Rep. 2014, 2, 1-7. [CrossRef]

10. Chen, Y.; Zhao, W.; Lin, L.; Xiao, X.; Zhou, X.; Ming, H.; Huang, T.; Liao, J.; Li, Y.; Zeng, X.; et al. Nasopharyngeal Epstein-Barr Virus Load: An Efficient Supplementary Method for Population-Based Nasopharyngeal Carcinoma Screening. PLoS ONE 2015, 10, e0132669. [CrossRef]

11. Minamoto, T.; Mai, M.; Ronai, Z.E. Environmental factors as regulators and effectors of multistep carcinogenesis. Carcinogenesis 1999, 20, 519-527. [CrossRef]

12. Broustas, C.G.; Lieberman, H.B. DNA damage response genes and the development of cancer metastasis. Radiat. Res. 2014, 181, 111-130. [CrossRef] [PubMed]

13. Zhou, K.; Liu, M.; Cao, Y. New Insight into microRNA Functions in Cancer: Oncogene-microRNA-Tumor Suppressor Gene Network. Front. Mol. Biosci. 2017, 4, 46. [CrossRef] [PubMed]

14. Miller, D.M.; Thomas, S.D.; Islam, A.; Muench, D.; Sedoris, K. c-Myc and cancer metabolism. Clin. Cancer Res. 2012, 18, 5546-5553. [CrossRef] [PubMed]

15. Ozaki, T.; Nakagawara, A. Role of p53 in Cell Death and Human Cancers. Cancers 2011, 3, $994-1013$. [CrossRef] [PubMed]

16. Giudice, A.; D’Arena, G.; Crispo, A.; Tecce, M.F.; Nocerino, F.; Grimaldi, M.; Rotondo, E.; D’Ursi, A.M.; Scrima, M.; Galdiero, M.; et al. Role of Viral miRNAs and Epigenetic Modifications in Epstein-Barr Virus-Associated Gastric Carcinogenesis. Oxid. Med. Cell Longev. 2016, 2016, 6021934. [CrossRef]

17. Jiang, N.; Liu, N.; Yang, F.; Zhou, Q.; Cui, R.; Jiang, W.; He, Q.; Li, W.; Guo, Y.; Zeng, J.; et al. Hotspot mutations in common oncogenes are infrequent in nasopharyngeal carcinoma. Oncol. Rep. 2014, 32, 1791-2431. [CrossRef]

18. Zhang, Z.-C.; Fu, S.; Wang, F.; Wang, H.-Y.; Zeng, Y.-X.; Shao, J.-Y. Oncogene mutational profile in nasopharyngeal carcinoma. OncoTargets Ther. 2014, 7, 457-467. [CrossRef]

19. Zhang, J.-W.; Qin, T.; Hong, S.-D.; Zhang, J.; Fang, W.-F.; Zhao, Y.-Y.; Yang, Y.-P.; Xue, C.; Huang, Y.; Zhao, H.-Y.; et al. Multiple oncogenic mutations related to targeted therapy in nasopharyngeal carcinoma. Chin. J. Cancer 2015, 34, 177-183. [CrossRef]

20. Chai, S.J.; Ahmad Zabidi, M.M.; Gan, S.P.; Rajadurai, P.; Lim, P.V.H.; Ng, C.C.; Yap, L.F.; Teo, S.H.; Lim, K.P.; Patel, V.; et al. An Oncogenic Role for Four-Jointed Box 1 (FJX1) in Nasopharyngeal Carcinoma. Dis. Markers 2019, 2019, 60803. [CrossRef]

21. Hu, C.; Wei, W.; Chen, X.; Woodman, C.B.; Yao, Y.; Nicholls, J.M.; Joab, I.; Sihota, S.K.; Shao, J.-Y.; Derkaoui, K.D.; et al. A Global View of the Oncogenic Landscape in Nasopharyngeal Carcinoma: An Integrated Analysis at the Genetic and Expression Levels. PLoS ONE 2012, 7, e41055. [CrossRef]

22. Scholle, F.; Bendt, K.M.; Raab-Traub, N. Epstein-Barr virus LMP2A transforms epithelial cells, inhibits cell differentiation, and activates Akt. J. Virol. 2000, 74, 10681-10689. [CrossRef] [PubMed]

23. Seto, E.; Ooka, T.; Middeldorp, J.; Takada, K. Reconstitution of Nasopharyngeal Carcinoma-Type EBV Infection Induces Tumorigenicity. Cancer Res. 2008, 68, 1030. [CrossRef] [PubMed]

24. Wang, A.; Zhang, W.; Jin, M.; Zhang, J.; Li, S.; Tong, F.; Zhou, Y. Differential expression of EBV proteins LMP1 and BHFR1 in EBV-associated gastric and nasopharyngeal cancer tissues. Mol. Med. Rep. 2016, 13, 4151-4158. [CrossRef] [PubMed]

25. Khabir, A.; Karray, H.; Rodriguez, S.; Rosé, M.; Daoud, J.; Frikha, M.; Boudawara, T.; Middeldorp, J.; Jlidi, R.; Busson, P. EBV latent membrane protein 1 abundance correlates with patient age but not with metastatic behavior in north African nasopharyngeal carcinomas. Virol. J. 2005, 2, 39. [CrossRef] 
26. Huang, D.P.; Lo, K.-W.; van Hasselt, C.A.; Woo, J.K.S.; Choi, P.H.K.; Leung, S.-F.; Cheung, S.-T.; Cairns, P.; Sidransky, D.; Lee, J.C.K. A Region of Homozygous Deletion on Chromosome 9p21-22 in Primary Nasopharyngeal Carcinoma. Cancer Res. 1994, 54, 4003.

27. Hui, A.B.; Lo, K.W.; Leung, S.F.; Choi, P.H.; Fong, Y.; Lee, J.C.; Huang, D.P. Loss of heterozygosity on the long arm of chromosome 11 in nasopharyngeal carcinoma. Cancer Res. 1996, 56, 0008-5472.

28. Lo, K.-W.; Kwong, J.; Hui, A.B.-Y.; Chan, S.Y.-Y.; To, K.-F.; Chan, A.S.-C.; Chow, L.S.-N.; Teo, P.M.L.; Johnson, P.J.; Huang, D.P. High Frequency of Promoter Hypermethylation of RASSF1A in Nasopharyngeal Carcinoma. Cancer Res. 2001, 61, 3877.

29. Tsang, Y.S.; Lo, K.W.; Leung, S.-F.; Choi, P.H.K.; Fong, Y.; Lee, J.C.K.; Huang, D.P. Two distinct regions of deletion on chromosome 13q in primary nasopharyngeal carcinoma. Int. J. Cancer 1999, 83, 305-308. [CrossRef]

30. Shao, Y.; Jiang, H.; Wu, X.; Luo, Y.; Tang, W. p16 promoter hypermethylation is associated with increased risk of nasopharyngeal carcinoma. Mol. Clin. Oncol. 2014, 2, 1121-1124. [CrossRef]

31. Wong, T.-S.; Kwong, D.L.-W.; Sham, J.S.-T.; Wei, W.I.; Kwong, Y.-L.; Yuen, A.P.-W. Quantitative Plasma Hypermethylated DNA Markers of Undifferentiated Nasopharyngeal Carcinoma. Clin. Cancer Res. 2004, 10, 2401. [CrossRef]

32. Tian, F.; Yip, S.; Kwong, D.; Lin, Z.; Yang, Z.; Wu, V. Promoter hypermethylation of tumor suppressor genes in serum as potential biomarker for the diagnosis of nasopharyngeal carcinoma. Cancer Epidemiol. 2013, 37, 708-713. [CrossRef]

33. Ayadi, W.; Karray-Hakim, H.; Khabir, A.; Feki, L.; Charfi, S.; Boudawara, T.; Ghorbel, A.; Daoud, J.; Frikha, M.; Busson, P.; et al. Aberrant methylation of p16, DLEC1, BLU and E-cadherin gene promoters in nasopharyngeal carcinoma biopsies from Tunisian patients. Anticancer Res. 2008, 28, 2161-2167.

34. Challouf, S.; Ziadi, S.; Zaghdoudi, R.; Ksiaa, F.; Ben Gacem, R.; Trimeche, M. Patterns of aberrant DNA hypermethylation in nasopharyngeal carcinoma in Tunisian patients. Clin. Chim. Acta 2012, 413, 795-802. [CrossRef]

35. Tong, J.H.M.; Tsang, R.K.Y.; Lo, K.-W.; Woo, J.K.S.; Kwong, J.; Chan, M.W.Y.; Chang, A.R.; van Hasselt, C.A.; Huang, D.P.; To, K.-F. Quantitative Epstein-Barr Virus DNA Analysis and Detection of Gene Promoter Hypermethylation in Nasopharyngeal (NP) Brushing Samples from Patients with NP Carcinoma. Clin. Cancer Res. 2002, 8, 2612. [PubMed]

36. Xiao, L.; Jiang, L.; Hu, Q.; Li, Y. Promoter methylation of p16 and DAPK genes in brushing, blood, and tissue samples from patients with nasopharyngeal carcinoma: A systematic meta-analysis. Transl. Cancer Res. 2016, 5, 827-837. [CrossRef]

37. Lo, K.-W.; Cheung, S.-T.; Leung, S.-F.; van Hasselt, A.; Tsang, Y.-S.; Mak, K.-F.; Chung, Y.-F.; Woo, J.K.S.; Lee, J.C.K.; Huang, D.P. Hypermethylation of the p16 Gene in Nasopharyngeal Carcinoma. Cancer Res. 1996, 56, 2721. [PubMed]

38. Chang, H.W.; Chan, A.; Kwong, D.L.W.; Wei, W.I.; Sham, J.S.T.; Yuen, A.P.W. Evaluation of hypermethylated tumor suppressor genes as tumor markers in mouth and throat rinsing fluid, nasopharyngeal swab and peripheral blood of nasopharygeal carcinoma patient. Int. J. Cancer 2003, 105, 851-855. [CrossRef]

39. Wong, T.S.; Tang, K.C.; Kwong, D.L.; Sham, J.S.; Wei, W.I.; Kwong, Y.L.; Yuen, A.P. Differential gene methylation in undifferentiated nasopharyngeal carcinoma. Int. J. Oncol. 2003, 22, 1019-6439. [CrossRef]

40. Fendri, A.; Masmoudi, A.; Khabir, A.; Sellami-Boudawara, T.; Daoud, J.; Frikha, M.; Ghorbel, A.; Gargouri, A.; Mokdad-Gargouri, R. Inactivation of RASSF1A, RAR 32 and DAP-kinase by promoter methylation correlates with lymph node metastasis in nasopharyngeal carcinoma. Cancer Biol. Ther. 2009, 8, 444-451. [CrossRef]

41. Kwong, J.; Lo, K.-W.; To, K.-F.; Teo, P.M.L.; Johnson, P.J.; Huang, D.P. Promoter Hypermethylation of Multiple Genes in Nasopharyngeal Carcinoma. Clin. Cancer Res. 2002, 8, 131.

42. Jiang, W.; Liu, N.; Chen, X.-Z.; Sun, Y.; Li, B.; Ren, X.-Y.; Qin, W.-F.; Jiang, N.; Xu, Y.-F.; Li, Y.-Q.; et al. Genome-Wide Identification of a Methylation Gene Panel as a Prognostic Biomarker in Nasopharyngeal Carcinoma. Mol. Cancer Ther. 2015, 14, 2864. [CrossRef] [PubMed]

43. Sze Wong, T.; Wen Chang, H.; Chi Tang, K.; Ignace Wei, W.; Lai Wen Kwong, D.; Sham, J.S.T.; Yuen, A.P.W.; Lam Kwong, Y. High Frequency of Promoter Hypermethylation of the DAP-kinase Gene in Nasopharyngeal Carcinoma and Its Detection in the Peripheral Blood of Patients. Clin. Cancer Res. 2002, 8, 433. 
44. Nawaz, I.; Moumad, K.; Martorelli, D.; Ennaji, M.M.; Zhou, X.; Zhang, Z.; Dolcetti, R.; Khyatti, M.; Ernberg, I.; Hu, L.-F. Detection of nasopharyngeal carcinoma in Morocco (North Africa) using a multiplex methylation-specific PCR biomarker assay. Clin. Epigenetics 2015, 7, 89. [CrossRef]

45. Yang, X.; Dai, W.; Kwong, D.L.-W.; Szeto, C.Y.Y.; Wong, E.H.-W.; Ng, W.T.; Lee, A.W.M.; Ngan, R.K.C.; Yau, C.C.; Tung, S.Y.; et al. Epigenetic markers for noninvasive early detection of nasopharyngeal carcinoma by methylation-sensitive high resolution melting. Int. J. Cancer 2015, 136, E127-E135. [CrossRef] [PubMed]

46. Ran, Y.; Wu, S.; You, Y. Demethylation of E-cadherin gene in nasopharyngeal carcinoma could serve as a potential therapeutic strategy. J. Biochem. 2010, 149, 49-54. [CrossRef] [PubMed]

47. Tsao, S.W.; Liu, Y.; Wang, X.; Yuen, P.W.; Leung, S.Y.; Yuen, S.T.; Pan, J.; Nicholls, J.M.; Cheung, A.L.M.; Wong, Y.C. The association of E-cadherin expression and the methylation status of the E-cadherin gene in nasopharyngeal carcinoma cells. Eur. J. Cancer 2003, 39, 524-531. [CrossRef]

48. Wong, T.S.; Kwong, D.L.-W.; Sham, J.S.-T.; Tsao, S.W.; Wei, W.I.; Kwong, Y.L.; Yuen, A.P.-W. Promoter Hypermethylation of High-in-normal 1 Gene in Primary Nasopharyngeal Carcinoma. Clin. Cancer Res. 2003, 9, 3042 .

49. Hutajulu, S.H.; Indrasari, S.R.; Indrawati, L.P.L.; Harijadi, A.; Duin, S.; Haryana, S.M.; Steenbergen, R.D.M.; Greijer, A.E.; Middeldorp, J.M. Epigenetic markers for early detection of nasopharyngeal carcinoma in a high risk population. Mol. Cancer 2011, 10, 48. [CrossRef]

50. Zhang, S.; Li, S.; Gao, J.-L. Promoter methylation status of the tumor suppressor gene SOX11 is associated with cell growth and invasion in nasopharyngeal carcinoma. Cancer Cell Int. 2013, 13, 109. [CrossRef]

51. Yi, B.; Tan, S.-X.; Tang, C.-E.; Huang, W.-G.; Cheng, A.-L.; Li, C.; Zhang, P.-F.; Li, M.-Y.; Li, J.-L.; Yi, H.; et al. Inactivation of 14-3-3 $\sigma$ by promoter methylation correlates with metastasis in nasopharyngeal carcinoma. J. Cell. Biochem. 2009, 106, 858-866. [CrossRef]

52. Zhang, D.; Zhou, J.; Gao, J.; Wu, R.-Y.; Huang, Y.-L.; Jin, Q.-W.; Chen, J.-S.; Tang, W.-Z.; Yan, L.-H. Targeting snoRNAs as an emerging method of therapeutic development for cancer. Am. J. Cancer Res. 2019, 9, 1504-1516. [PubMed]

53. Liang, J.; Wen, J.; Huang, Z.; Chen, X.-P.; Zhang, B.-X.; Chu, L. Small Nucleolar RNAs: Insight into Their Function in Cancer. Front. Oncol. 2019, 9, 587. [CrossRef] [PubMed]

54. Liu, D.; Wang, Y.; Zhao, Y.; Gu, X. LncRNA SNHG5 promotes nasopharyngeal carcinoma progression by regulating miR-1179/HMGB3 axis. BMC Cancer 2020, 20, 178. [CrossRef] [PubMed]

55. Dai, Y.; Zhang, X.; Xing, H.; Zhang, Y.; Cao, H.; Sang, J.; Gao, L.; Wang, L. Downregulated long non-coding RNA SNHG7 restricts proliferation and boosts apoptosis of nasopharyngeal carcinoma cells by elevating microRNA-140-5p to suppress GLI3 expression. Cell Cycle 2020, 19, 448-463. [CrossRef]

56. Xu, W.; Sun, X.; Zang, C.; Jiang, Y. lncRNA SNHG7 promotes tumorigenesis of nasopharyngeal carcinoma via epithelial-to-mesenchymal transition. Oncol. Lett. 2020, 19, 2721-2726. [CrossRef]

57. Liu, Z.-B.; Tang, C.; Jin, X.; Liu, S.-H.; Pi, W. Increased expression of lncRNA SNHG12 predicts a poor prognosis of nasopharyngeal carcinoma and regulates cell proliferation and metastasis by modulating Notch signal pathway. Cancer Biomark. 2018, 23, 603-613. [CrossRef]

58. Sun, C.; Sun, Y.; Zhang, E. Long non-coding RNA SNHG20 promotes nasopharyngeal carcinoma cell migration and invasion by upregulating TGF- $\beta 1$. Exp. Ther. Med. 2018, 16, 4967-4974. [CrossRef]

59. Iorio, M.V.; Croce, C.M. microRNA involvement in human cancer. Carcinogenesis 2012, 33, $1126-1133$. [CrossRef]

60. Li, Y.; Yan, L.; Zhang, W.; Wang, H.; Chen, W.; Hu, N.; Ou, H. miR-21 inhibitor suppresses proliferation and migration of nasopharyngeal carcinoma cells through down-regulation of BCL2 expression. Int. J. Clin. Exp. Pathol. 2014, 7, 3478-3487.

61. Tan, G.; Tang, X.; Tang, F. The role of microRNAs in nasopharyngeal carcinoma. Tumour Biol. 2015, 36, 69-79. [CrossRef]

62. Spence, T.; Bruce, J.; Yip, K.W.; Liu, F.-F. MicroRNAs in nasopharyngeal carcinoma. Chin. Clin. Oncol. 2016, 5, 17. [CrossRef] [PubMed]

63. Wang, S.; Claret, F.-X.; Wu, W. MicroRNAs as Therapeutic Targets in Nasopharyngeal Carcinoma. Front. Oncol. 2019, 9, 756. [CrossRef] [PubMed]

64. Yu, L.; Lu, J.; Zhang, B.; Liu, X.; Wang, L.; Li, S.-Y.; Peng, X.-H.; Xu, X.; Tian, W.-D.; Li, X.-P. miR-26a inhibits invasion and metastasis of nasopharyngeal cancer by targeting EZH2. Oncol. Lett. 2013, 5, 1223-1228. [CrossRef] [PubMed] 
65. Alajez, N.M.; Shi, W.; Hui, A.B.Y.; Bruce, J.; Lenarduzzi, M.; Ito, E.; Yue, S.; O'Sullivan, B.; Liu, F.F. Enhancer of Zeste homolog 2 (EZH2) is overexpressed in recurrent nasopharyngeal carcinoma and is regulated by miR-26a, miR-101, and miR-98. Cell Death Dis. 2010, 1, e85. [CrossRef]

66. Liu, N.; Ling-Long, T.; Yung, S.; Rui-Xue, C.; Hui-Yun, W.; Bi-Jun, H.; Qing-Mei, H.; Wei, J.; Jun, M. MiR-29c suppresses invasion and metastasis by targeting TIAM1 in nasopharyngeal carcinoma. Cancer Lett. 2013, 392, 1872-7980. [CrossRef]

67. Jia-Xing, Z.; D'ong, Q.; Feng-Wei, W.; D'ing-Zhun, L.; Jin-Huan, W.; Zhu-Ting, T.; Jia, F.; Xiao-Xia, H.; Yi-Ji, L.; Hai-Xia, D.; et al. MicroRNA-29c enhances the sensitivities of human nasopharyngeal carcinoma to cisplatin-based chemotherapy and radiotherapy. Cancer Lett. 2013, 329, 1872-7980.

68. Xia, H.; Samuel, S.N.; Songshan, J.; William, K.C.C.; Johny, S.; Xiu-Wi, B.; Hsiang-Fu, K.; Marie, C.L. miR-200a-mediated downregulation of ZEB2 and CTNNB1 differentially inhibits nasopharyngeal carcinoma cell growth, migration and invasion. Biochem. Biophys. Res. Commun. 2010, 391, 1090-2104. [CrossRef]

69. Wong, T.S.; Man, O.Y.; Tsang, C.M.; Tsao, S.W.; Tsang, R.K.Y.; Chan, J.Y.W.; Ho, W.K.; Wei, W.I.; To, V.S.H. MicroRNA let-7 suppresses nasopharyngeal carcinoma cells proliferation through downregulating c-Myc expression. J. Cancer Res. Clin. Oncol. 2011, 137, 415-422. [CrossRef]

70. Wu, A.; Wu, K.; Li, J.; Mo, Y.; Lin, Y.; Wang, Y.; Shen, X.; Li, S.; Li, L.; Yang, Z. Let-7a inhibits migration, invasion and epithelial-mesenchymal transition by targeting HMGA2 in nasopharyngeal carcinoma. J. Transl. Med. 2015, 13, 105. [CrossRef]

71. Peng, X.H.; Huang, H.R.; Lu, J.; Liu, X.; Zhao, F.P.; Zhang, B.; Lin, S.X.; Wang, L.; Chen, H.H.; Xu, X.; et al. MiR-124 suppresses tumor growth and metastasis by targeting Foxq1 in nasopharyngeal carcinoma. Mol. Cancer 2014, 13, 186. [CrossRef]

72. Liu, N.; Jiang, N.; Guo, R.; Jiang, W.; He, Q.-M.; Xu, Y.-F.; Li, Y.-Q.; Tang, L.-L.; Mao, Y.-P.; Sun, Y.; et al. MiR-451 inhibits cell growth and invasion by targeting MIF and is associated with survival in nasopharyngeal carcinoma. Mol. Cancer 2013, 12, 123. [CrossRef] [PubMed]

73. Deng, M.; Liu, J.F.; Gu, Y.X.; Zheng, G.P.; He, Z.M. miR-216b suppresses cell proliferation and invasion by targeting PKC $\alpha$ in nasopharyngeal carcinoma cells. Zhonghua Zhong Liu Za Zhi 2013, 35, 645-650. [PubMed]

74. Deng, M.; Tang, H.; Zhou, Y.; Zhou, M.; Xiong, W.; Zheng, Y.; Ye, Q.; Zeng, X.; Liao, Q.; Guo, X.; et al. miR-216b suppresses tumor growth and invasion by targeting KRAS in nasopharyngeal carcinoma. J. Cell Sci. 2011, 124, 2997. [CrossRef] [PubMed]

75. Hui, A.B.Y.; Bruce, J.P.; Alajez, N.M.; Shi, W.; Yue, S.; Perez-Ordonez, B.; Xu, W.; Sullivan, B.; Waldron, J.; Cummings, B.; et al. Significance of Dysregulated Metadherin and MicroRNA-375 in Head and Neck Cancer. Clin. Cancer Res. 2011, 17, 7539. [CrossRef] [PubMed]

76. Liu, X.; Luo, H.-N.; Tian, W.-D.; Lu, J.; Li, G.; Wang, L.; Zhang, B.; Liang, B.-J.; Peng, X.-H.; Lin, S.-X.; et al. Diagnostic and prognostic value of plasma microRNA deregulation in nasopharyngeal carcinoma. Cancer Biol. Ther. 2013, 14, 1133-1142. [CrossRef]

77. Luo, Z.; Dai, Y.; zhang, L.; Jiang, C.; Li, Z.; Yang, J.; McCarthy, J.B.; She, X.; Zhang, W.; Ma, J.; et al. miR-18a promotes malignant progression by impairing microRNA biogenesis in nasopharyngeal carcinoma. Carcinogenesis 2012, 34, 415-425. [CrossRef]

78. Yu, X.; Zhen, Y.; Yang, H.; Wang, H.; Zhou, Y.; Wang, E.; Marincola, F.M.; Mai, C.; Chen, Y.; Wei, H.; et al. Loss of connective tissue growth factor as an unfavorable prognosis factor activates miR-18b by PI3K/AKT/C-Jun and C-Myc and promotes cell growth in nasopharyngeal carcinoma. Cell Death Dis. 2013, 4, e634. [CrossRef]

79. Zhang, L.; Deng, T.; Li, X.; Liu, H.; Zhou, H.; Ma, J.; Wu, M.; Zhou, M.; Shen, S.; Li, X.; et al. microRNA-141 is involved in a nasopharyngeal carcinoma-related genes network. Carcinogenesis 2010, 31, 559-566. [CrossRef]

80. Deng, M.; Ye, Q.; Qin, Z.; Zheng, Y.; He, W.; Tang, H.; Zhou, Y.; Xiong, W.; Zhou, M.; Li, X.; et al. miR-214 promotes tumorigenesis by targeting lactotransferrin in nasopharyngeal carcinoma. Tumor Biol. 2013, 34, 1793-1800. [CrossRef]

81. Wang, H.-Y.; Li, Y.-Y.; Fu, S.; Wang, X.-P.; Huang, M.-Y.; Zhang, X.; Shao, Q.; Deng, L.; Zeng, M.-S.; Zeng, Y.-X.; et al. MicroRNA-30a promotes invasiveness and metastasis in vitro and in vivo through epithelial-mesenchymal transition and results in poor survival of nasopharyngeal carcinoma patients. Exp. Biol. Med. 2014, 239, 891-898. [CrossRef] 
82. Luo, Z.; Zhang, L.; Li, Z.; Jiang, C.; Dai, Y.; Liu, X.; Zheng, Y.; Yu, H.; Xiang, J.; Li, G. miR-149 promotes epithelial-mesenchymal transition and invasion in nasopharyngeal carcinoma cells. Zhong Nan Da Xue Xue Bao Yi Xue Ban 2011, 36, 604-609. [PubMed]

83. Du, Z.-M.; Hu, L.-F.; Wang, H.-Y.; Yan, L.-X.; Zeng, Y.-X.; Shao, J.-Y.; Ernberg, I. Upregulation of MiR-155 in Nasopharyngeal Carcinoma is Partly Driven by LMP1 and LMP2A and Downregulates a Negative Prognostic Marker JMJD1A. PLoS ONE 2011, 6, e19137. [CrossRef] [PubMed]

84. Zhao, L.; Tang, M.; Hu, Z.; Yan, B.; Pi, W.; Li, Z.; Zhang, J.; Zhang, L.; Jiang, W.; Li, G.; et al. miR-504 mediated down-regulation of nuclear respiratory factor 1 leads to radio-resistance in nasopharyngeal carcinoma. Oncotarget 2015, 6, 15995-16018. [CrossRef] [PubMed]

85. Wang, Y.; Guo, Z.; Shu, Y.; Zhou, H.; Wang, H.; Zhang, W. BART miRNAs: An unimaginable force in the development of nasopharyngeal carcinoma. Eur. J. Cancer Prev. 2017, 26, 144-150. [CrossRef] [PubMed]

86. Xu, X.; Lu, J.; Wang, F.; Liu, X.; Peng, X.; Yu, B.; Zhao, F.; Li, X. Dynamic Changes in Plasma MicroRNAs Have Potential Predictive Values in Monitoring Recurrence and Metastasis of Nasopharyngeal Carcinoma. BioMed Res. Int. 2018, 2018, 7329195. [CrossRef]

87. Lu, J.; Xu, X.; Liu, X.; Peng, Y.; Zhang, B.; Wang, L.; Luo, H.; Peng, X.; Li, G.; Tian, W.; et al. Predictive value of miR-9 as a potential biomarker for nasopharyngeal carcinoma metastasis. Br. J. Cancer 2014, 110, 392-398. [CrossRef]

88. Wang, H.; Peng, R.; Wang, J.; Qin, Z.; Xue, L. Circulating microRNAs as potential cancer biomarkers: The advantage and disadvantage. Clin. Epigenetics 2018, 10, 59. [CrossRef]

89. Zeng, X.; Xiang, J.; Wu, M.; Xiong, W.; Tang, H.; Deng, M.; Li, X.; Liao, Q.; Su, B.; Luo, Z.; et al. Circulating $\mathrm{miR}-17$, miR-20a, miR-29c, and miR-223 combined as non-invasive biomarkers in nasopharyngeal carcinoma. PLoS ONE 2012, 7, e46367. [CrossRef]

90. Liu, N.; Cui, R.-X.; Sun, Y.; Guo, R.; Mao, Y.-P.; Tang, L.-L.; Jiang, W.; Liu, X.; Cheng, Y.-K.; He, Q.-M.; et al. A four-miRNA signature identified from genome-wide serum miRNA profiling predicts survival in patients with nasopharyngeal carcinoma. Int. J. Cancer 2014, 134, 1359-1368. [CrossRef]

91. He, Y.; Zhang, L.; Cheng, G.; Yuan, R.; Zhuang, Y.; Zhang, D.; Zhou, D.; Xu, X. Upregulation of circulating miR-21 is associated with poor prognosis of nasopharyngeal carcinoma. Int. J. Clin. Exp. Pathol. 2017, 10, 7362-7368.

92. Miao, B.-P.; Zhang, R.-S.; Li, M.; Fu, Y.-T.; Zhao, M.; Liu, Z.-G.; Yang, P.-C. Nasopharyngeal cancer-derived microRNA-21 promotes immune suppressive B cells. Cell. Mol. Immunol. 2015, 12, 750-756. [CrossRef] [PubMed]

93. Marquitz, A.R.; Raab-Traub, N. The role of miRNAs and EBV BARTs in NPC. Semin. Cancer Biol. 2012, 22, 166-172. [CrossRef] [PubMed]

94. Ye, Y.; Zhou, Y.; Zhang, L.; Chen, Y.; Lyu, X.; Cai, L.; Lu, Y.; Deng, Y.; Wang, J.; Yao, K.; et al. EBV-miR-BART1 is involved in regulating metabolism-associated genes in nasopharyngeal carcinoma. Biochem. Biophys. Res. Commun. 2013, 436, 19-24. [CrossRef] [PubMed]

95. Chen, S.-J.; Chen, G.-H.; Chen, Y.-H.; Liu, C.-Y.; Chang, K.-P.; Chang, Y.-S.; Chen, H.-C. Characterization of Epstein-Barr virus miRNAome in nasopharyngeal carcinoma by deep sequencing. PLoS ONE 2010, 5, e12745. [CrossRef] [PubMed]

96. Gourzones, C.; Ferrand, F.-R.; Amiel, C.; Vérillaud, B.; Barat, A.; Guérin, M.; Gattolliat, C.-H.; Gelin, A.; Klibi, J.; Chaaben, A.B.; et al. Consistent high concentration of the viral microRNA BART17 in plasma samples from nasopharyngeal carcinoma patients-evidence of non-exosomal transport. Virol. J. 2013, 10, 119. [CrossRef] [PubMed]

97. Chan, J.Y.; Gao, W.; Ho, W.K.; Wei, W.I.; Wong, T.S. Overexpression of Epstein-Barr virus-encoded microRNA-BART7 in undifferentiated nasopharyngeal carcinoma. Anticancer Res. 2012, 32, 1791-7530.

98. Zhang, G.; Zong, J.; Lin, S.; Verhoeven, R.J.A.; Tong, S.; Chen, Y.; Ji, M.; Cheng, W.; Tsao, S.-W.; Lung, M.; et al. Circulating Epstein-Barr virus microRNAs miR-BART7 and miR-BART13 as biomarkers for nasopharyngeal carcinoma diagnosis and treatment. Int. J. Cancer 2015, 136, E301-E312. [CrossRef]

99. Zhang, J.; Li, X.; Hu, J.; Cao, P.; Yan, Q.; Zhang, S.; Dang, W.; Lu, J. Long noncoding RNAs involvement in Epstein-Barr virus infection and tumorigenesis. Virol. J. 2020, 17, 51. [CrossRef] 
100. Zhang, W.; Huang, C.; Gong, Z.; Zhao, Y.; Tang, K.; Li, X.; Fan, S.; Shi, L.; Li, X.; Zhang, P.; et al. Expression of LINC00312, a long intergenic non-coding RNA, is negatively correlated with tumor size but positively correlated with lymph node metastasis in nasopharyngeal carcinoma. J. Mol. Histol. 2013, 44, 545-554. [CrossRef]

101. Zhang, W.; Du, M.; Wang, T.; Chen, W.; Wu, J.; Li, Q.; Tian, X.; Qian, L.; Wang, Y.; Peng, F.; et al. Long non-coding RNA LINC01133 mediates nasopharyngeal carcinoma tumorigenesis by binding to YBX1. Am. J. Cancer Res. 2019, 9, 779-790.

102. Kong, J.; Sun, W.; Li, C.; Wan, L.; Wang, S.; Wu, Y.; Xu, E.; Zhang, H.; Lai, M. Long non-coding RNA LINC01133 inhibits epithelial-mesenchymal transition and metastasis in colorectal cancer by interacting with SRSF6. Cancer Lett. 2016, 380, 476-484. [CrossRef] [PubMed]

103. Kong, J.; Sun, W.; Zhu, W.; Liu, C.; Zhang, H.; Wang, H. Long noncoding RNA LINC01133 inhibits oral squamous cell carcinoma metastasis through a feedback regulation loop with GDF15. J. Surg. Oncol. 2018, 118. [CrossRef] [PubMed]

104. Yang, X.-Z.; Cheng, T.-T.; He, Q.-J.; Lei, Z.-Y.; Chi, J.; Tang, Z.; Liao, Q.-X.; Zhang, H.; Zeng, L.-S.; Cui, S.-Z. LINC01133 as ceRNA inhibits gastric cancer progression by sponging miR-106a-3p to regulate APC expression and the Wnt/ $\beta$-catenin pathway. Mol. Cancer 2018, 17, 126. [CrossRef] [PubMed]

105. He, Y.; Jing, Y.; Wei, F.; Tang, Y.; Yang, L.; Luo, J.; Yang, P.; Ni, Q.; Pang, J.; Liao, Q.; et al. Long non-coding RNA PVT1 predicts poor prognosis and induces radioresistance by regulating DNA repair and cell apoptosis in nasopharyngeal carcinoma. Cell Death Dis. 2018, 9, 235. [CrossRef] [PubMed]

106. Shen, M.; Li, M.; Liu, J. Long Noncoding RNA HOTTIP Promotes Nasopharyngeal Cancer Cell Proliferation, Migration, and Invasion by Inhibiting miR-4301. Med. Sci. Monit. 2019, 25, 778-785. [CrossRef] [PubMed]

107. Nie, Y.; Liu, X.; Qu, S.; Song, E.; Zou, H.; Gong, C. Long non-coding RNA HOTAIR is an independent prognostic marker for nasopharyngeal carcinoma progression and survival. Cancer Sci. 2013, 104, 458-464. [CrossRef] [PubMed]

108. Li, L.; Gu, M.; You, B.; Shi, S.; Shan, Y.; Bao, L.; You, Y. Long non-coding RNA ROR promotes proliferation, migration and chemoresistance of nasopharyngeal carcinoma. Cancer Sci. 2016, 107, 1215-1222. [CrossRef]

109. Song, P.; Ye, L.-F.; Zhang, C.; Peng, T.; Zhou, X.-H. Long non-coding RNA XIST exerts oncogenic functions in human nasopharyngeal carcinoma by targeting miR-34a-5p. Gene 2016, 592, 8-14. [CrossRef]

110. Zhuang, K.; Wu, Q.; Jin, C.-S.; Yuan, H.-J.; Cheng, J.-Z. Long non-coding RNA HNF1A-AS is upregulated and promotes cell proliferation and metastasis in nasopharyngeal carcinoma. Cancer Biomark. 2016, 16, 291-300. [CrossRef]

111. Liao, B.; Wang, Z.; Zhu, Y.; Wang, M.; Liu, Y. Long noncoding RNA DRAIC acts as a microRNA-122 sponge to facilitate nasopharyngeal carcinoma cell proliferation, migration and invasion via regulating SATB1. Artif. Cells Nanomed. Biotechnol. 2019, 47, 3585-3597. [CrossRef]

112. Su, H.; Liu, L.; Zhang, Y.; Wang, J.; Zhao, Y. Long noncoding RNA NPCCAT1 promotes nasopharyngeal carcinoma progression via upregulating YY1. Biochimie 2019, 157, 184-194. [CrossRef] [PubMed]

113. Wu, J.-H.; Tang, J.-M.; Li, J.; Li, X.-W. Upregulation of SOX2-activated lncRNA ANRIL promotes nasopharyngeal carcinoma cell growth. Sci. Rep. 2018, 8, 3333. [CrossRef] [PubMed]

114. Li, X.; Lin, Y.; Yang, X.; Wu, X.; He, X. Long noncoding RNA H19 regulates EZH2 expression by interacting with miR-630 and promotes cell invasion in nasopharyngeal carcinoma. Biochem. Biophys. Res. Commun. 2016, 473, 913-919. [CrossRef] [PubMed]

115. He, S.-W.; Xu, C.; Li, Y.-Q.; Li, Y.-Q.; Zhao, Y.; Zhang, P.-P.; Lei, Y.; Liang, Y.-L.; Li, J.-Y.; Li, Q.; et al. AR-induced long non-coding RNA LINC01503 facilitates proliferation and metastasis via the SFPQ-FOSL1 axis in nasopharyngeal carcinoma. Oncogene 2020, 1-17. [CrossRef] [PubMed]

116. Xue, M.Y.; Cao, H.X. Long non-coding RNA CASC15 promotes nasopharyngeal carcinoma cell proliferation and metastasis by downregulating miR-101-3p. Eur. Rev. Med. Pharmacol. Sci. 2019, 23, 8897-8904. [PubMed]

117. Jia, X.; Niu, P.; Xie, C.; Liu, H. Long noncoding RNA PXN-AS1-L promotes the malignancy of nasopharyngeal carcinoma cells via upregulation of SAPCD2. Cancer Med. 2019, 8, 4278-4291. [CrossRef]

118. Hu, X.; Liu, W.; Jiang, X.; Wang, B.; Li, L.; Wang, J.; Ma, J. Long noncoding RNA LINC00460 aggravates invasion and metastasis by targeting miR-30a-3p/Rap1A in nasopharyngeal carcinoma. Human Cell 2019, 32, 465-476. [CrossRef]

119. Liu, C.; Zhang, H.; Liu, H. Long Noncoding RNA UCA1 Accelerates Nasopharyngeal Carcinoma Cell Progression by Modulating miR-124-3p/ITGB1 Axis. OncoTargets Ther 2019, 12, 8455-8466. [CrossRef] 
120. Li, L.; Zhang, F. Novel long noncoding RNA LINC01385 promotes nasopharyngeal carcinoma proliferation via the miR-140-3p/Twist1 signaling pathway. Cell Cycle 2020, 19, 1352-1362. [CrossRef]

121. Song, P.; Yin, S.-C. Long non-coding RNA 319 facilitates nasopharyngeal carcinoma carcinogenesis through regulation of miR-1207-5p/KLF12 axis. Gene 2019, 680, 51-58. [CrossRef]

122. Cui, Z.; Pu, T.; Zhang, Y.; Wang, J.; Zhao, Y. Long non-coding RNA LINC00346 contributes to cisplatin resistance in nasopharyngeal carcinoma by repressing miR-342-5p. Open Biol. 2020, 10, 190286. [CrossRef] [PubMed]

123. Jin, C.; Yan, B.; Lu, Q.; Lin, Y.; Ma, L. The role of MALAT1/miR-1/slug axis on radioresistance in nasopharyngeal carcinoma. Tumor Biol. 2016, 37, 4025-4033. [CrossRef] [PubMed]

124. Lu, Y.; Li, T.; Wei, G.; Liu, L.; Chen, Q.; Xu, L.; Zhang, K.; Zeng, D.; Liao, R. The long non-coding RNA NEAT1 regulates epithelial to mesenchymal transition and radioresistance in through miR-204/ZEB1 axis in nasopharyngeal carcinoma. Tumor Biol. 2016, 37, 11733-11741. [CrossRef] [PubMed]

125. Chen, L.; Sun, L.; Dong, L.; Cui, P.; Xia, Z.; Li, C.; Zhu, Y. The role of long noncoding RNA-LET in cell proliferation and invasion of nasopharyngeal carcinoma and its mechanism. OncoTargets Ther. 2017, 10, 2769-2778. [CrossRef]

126. Chak, W.-P.; Lung, R.W.-M.; Tong, J.H.-M.; Chan, S.Y.-Y.; Lun, S.W.-M.; Tsao, S.-W.; Lo, K.-W.; To, K.-F. Downregulation of long non-coding RNA MEG3 in nasopharyngeal carcinoma. Mol. Carcinog. 2017, 56, 1041-1054. [CrossRef]

127. Guo, J.; Ma, J.; Zhao, G.; Li, G.; Fu, Y.; Luo, Y.; Gui, R. Long Noncoding RNA LINC0086 Functions as a Tumor Suppressor in Nasopharyngeal Carcinoma by Targeting miR-214. Oncol. Res. 2017, 25, 1189-1197. [CrossRef]

128. Xu, Y.-Z.; Chen, F.-F.; Zhang, Y.; Liang, H.; Li, X.-J.; He, C. Identification of potential long noncoding RNA associated with nasopharyngeal carcinoma using deep sequencing. J. Int. Med Res. 2019, 47, 3271-3281. [CrossRef]

129. Chen, S.; Luo, X.; Wu, W.; Li, Y.; Yu, H.; Wang, Y.; Yan, J. The long non-coding RNA MACC1-AS1 promotes nasopharyngeal carcinoma cell stemness via suppressing miR-145-mediated inhibition on SMAD2/MACC1-AS1 axis. Biomed. Pharmacother. 2020, 125, 109986. [CrossRef]

130. He, B.; Zeng, J.; Chao, W.; Chen, X.; Huang, Y.; Deng, K.; Huang, Z.; Li, J.; Dai, M.; Chen, S.; et al. Serum long non-coding RNAs MALAT1, AFAP1-AS1 and AL359062 as diagnostic and prognostic biomarkers for nasopharyngeal carcinoma. Oncotarget 2017, 8, 41166-41177. [CrossRef]

131. Fu, W.-M.; Lu, Y.-F.; Hu, B.-G.; Liang, W.-C.; Zhu, X.; Yang, H.-d.; Li, G.; Zhang, J.-F. Long noncoding RNA Hotair mediated angiogenesis in nasopharyngeal carcinoma by direct and indirect signaling pathways. Oncotarget 2016, 7, 4712-4723. [CrossRef]

132. He, B.; Li, W.; Wu, Y.; Wei, F.; Gong, Z.; Bo, H.; Wang, Y.; Li, X.; Xiang, B.; Guo, C.; et al. Epstein-Barr virus-encoded miR-BART6-3p inhibits cancer cell metastasis and invasion by targeting long non-coding RNA LOC553103. Cell Death Dis. 2016, 7, e2353. [CrossRef] [PubMed]

133. Zhang, J.; Zhang, S.; Zuo, L.; Yue, W.; Li, S.; Xin, S.; Liu, L.; Lu, J. Differential expression profiling of lncRNAs related to Epstein-Barr virus infection in the epithelial cells. J. Med Virol. 2019, 91, 1845-1855. [CrossRef] [PubMed]

134. Marrugo-Ramírez, J.; Mir, M.; Samitier, J. Blood-Based Cancer Biomarkers in Liquid Biopsy: A Promising Non-Invasive Alternative to Tissue Biopsy. Int. J. Mol. Sci. 2018, 19, 2877. [CrossRef] [PubMed]

135. Zhang, P.-F.; Zheng, X.-H.; Li, X.-Z.; Tian, T.; Zhang, S.-D.; Hu, Y.-Z.; Jia, W.-H. Nasopharyngeal brushing: A convenient and feasible sampling method for nucleic acid-based nasopharyngeal carcinoma research. Cancer Commun. 2018, 38, 8. [CrossRef]

136. Lao, T.D.; Nguyen, T.V.; Nguyen, D.H.; Nguyen, M.T.; Nguyen, C.H.; Le, T.H.A. miR-141 is up-regulated in biopsies from Vietnamese patients with nasopharyngeal carcinoma. Braz. Oral Res. 2018, 32, e126. [CrossRef]

137. Chang, H.W.; Chan, A.; Kwong, D.L.W.; Wei, W.I.; Sham, J.S.T.; Yuen, A.P.W. Detection of Hypermethylated RIZ1 Gene in Primary Tumor, Mouth, and Throat Rinsing Fluid, Nasopharyngeal Swab, and Peripheral Blood of Nasopharyngeal Carcinoma Patient. Clin. Cancer Res. 2003, 9, 1033.

138. Peng, D.; Ren, C.-P.; Yi, H.-M.; Zhou, L.; Yang, X.-Y.; Li, H.; Yao, K.-T. Genetic and Epigenetic Alterations of DLC-1, a Candidate Tumor Suppressor Gene, in Nasopharyngeal Carcinoma. Acta Biochim. Biophys. Sin. 2006, 38, 349-355. [CrossRef]

139. Li, J.; Gong, P.; Lyu, X.; Yao, K.; Li, X.; Peng, H. Aberrant CpG island methylation of PTEN is an early event in nasopharyngeal carcinoma and a potential diagnostic biomarker. Oncol. Rep. 2014, 31, 1791-2431. [CrossRef] 
140. Lu, J.; Luo, H.; Liu, X.; Peng, Y.; Zhang, B.; Wang, L.; Xu, X.; Peng, X.; Li, G.; Tian, W.; et al. miR-9 targets CXCR4 and functions as a potential tumor suppressor in nasopharyngeal carcinoma. Carcinogenesis 2013, 35, 554-563. [CrossRef]

141. Bar-Sela, G.; Kuten, A.; Ben-Eliezer, S.; Gov-Ari, E.; Ben-Izhak, O. Expression of HER2 and C-KIT in Nasopharyngeal Carcinoma: Implications for a New Therapeutic Approach. Mod. Pathol. 2003, 16, 1035-1040. [CrossRef]

142. Wang, X.; Huang, Y.; Guo, R.; Liu, Y.; Qian, Y.; Liu, D.; Dai, X.; Wei, Z.; Jin, F.; Liu, Y. Clinicopathological significance of ROCK1 and PIK3CA expression in nasopharyngeal carcinoma. Exp. Ther. Med. 2017, 13, 1064-1068. [CrossRef] [PubMed]

143. Xianglan, M.; Wu, Y.; Yongta, H.; Wenwen, G.; Minyan, Z.; Hongtao, Y. Expression of miR-3182 and EBV-miR-BART8-3p in nasopharyngeal carcinoma is correlated with distant metastasis. Int. J. Clin. Exp. Pathol. 2018, 11, 3134-3140.

144. Chen, X.; Wang, J.; Cheng, L.; Lu, M.-P. miR-18a downregulates DICER1 and promotes proliferation and metastasis of nasopharyngeal carcinoma. Int. J. Clin. Exp. Med. 2014, 7, 847-855. [PubMed]

145. Wahyuningsih, L.; Dwianingsih, E.K.; Risanti, E.D.; Tirtoprodjo, P.; Rinonce, H.T.; Hakim, F.A.; Herdini, C.; Fachiroh, J. Tissue P16 is Associated with Smoking Status among Indonesian Nasopharyngeal Carcinoma Subjects. Asian Pac. J. Cancer Prev. 2019, 20, 2125-2130. [CrossRef]

146. Hutajulu, S.H.; Hoebe, E.K.; Verkuijlen, S.A.; Fachiroh, J.; Hariwijanto, B.; Haryana, S.M.; Stevens, S.J.; Greijer, A.E.; Middeldorp, J.M. Conserved mutation of Epstein-Barr virus-encoded BamHI-A Rightward Frame-1 (BARF1) gene in Indonesian nasopharyngeal carcinoma. Infect. Agents Cancer 2010, 5, 16. [CrossRef]

147. Zheng, X.-H.; Lu, L.-X.; Cui, C.; Chen, M.-Y.; Li, X.-Z.; Jia, W.-H. Epstein-Barr virus mir-bart1-5p detection via nasopharyngeal brush sampling is effective for diagnosing nasopharyngeal carcinoma. Oncotarget 2016, 7, 4972-4980. [CrossRef]

148. Hao, S.-P.; Tsang, N.-M.; Chang, K.-P. Screening nasopharyngeal carcinoma by detection of the latent membrane protein 1 (LMP-1) gene with nasopharyngeal swabs. Cancer 2003, 97, 1909-1913. [CrossRef]

149. Chung, A.-K.; OuYang, C.-N.; Liu, H.; Chao, M.; Luo, J.-D.; Lee, C.-Y.; Lu, Y.-J.; Chung, I.C.; Chen, L.-C.; $\mathrm{Wu}, \mathrm{S}$.-M.; et al. Targeted sequencing of cancer-related genes in nasopharyngeal carcinoma identifies mutations in the TGF- $\beta$ pathway. Cancer Med. 2019, 8, 5116-5127. [CrossRef]

150. Aga, M.; Bentz, G.L.; Raffa, S.; Torrisi, M.R.; Kondo, S.; Wakisaka, N.; Yoshizaki, T.; Pagano, J.S.; Shackelford, J. Exosomal HIF1 $\alpha$ supports invasive potential of nasopharyngeal carcinoma-associated LMP1-positive exosomes. Oncogene 2014, 33, 4613-4622. [CrossRef]

151. Zhou, Y.; Xia, L.; Lin, J.; Wang, H.; Oyang, L.; Tan, S.; Tian, Y.; Su, M.; Wang, H.; Cao, D.; et al. Exosomes in Nasopharyngeal Carcinoma. J. Cancer 2018, 9, 767-777. [CrossRef]

152. Lu, J.; Liu, Q.-H.; Wang, F.; Tan, J.-J.; Deng, Y.-Q.; Peng, X.-H.; Liu, X.; Zhang, B.; Xu, X.; Li, X.-P. Exosomal miR-9 inhibits angiogenesis by targeting MDK and regulating PDK/AKT pathway in nasopharyngeal carcinoma. $J$. Exp. Clin. Cancer Res. 2018, 37, 147. [CrossRef] [PubMed]

153. Yue, P.Y.-K.; Ha, W.-Y.; Lau, C.-C.; Cheung, F.M.-F.; Lee, A.W.-M.; Ng, W.-T.; Ngan, R.K.-C.; Yau, C.-C.; Kwong, D.L.-W.; Lung, H.-L.; et al. MicroRNA profiling study reveals miR-150 in association with metastasis in nasopharyngeal carcinoma. Sci. Rep. 2017, 7, 12012. [CrossRef] [PubMed]

(C) 2020 by the authors. Licensee MDPI, Basel, Switzerland. This article is an open access article distributed under the terms and conditions of the Creative Commons Attribution (CC BY) license (http://creativecommons.org/licenses/by/4.0/). 